\title{
CEO chairman controversy: evidence from the post financial crisis period
}

\author{
Walter Gontarek $^{1}$ (D) $\cdot$ Yacine Belghitar $^{1}$
}

Published online: 13 July 2020

(c) The Author(s) 2020

\begin{abstract}
Regulators generally discourage bank CEOs also holding the role of board Chairman, as this governance structure can hinder independent decision-making and effective risk oversight. This study examines the issue of CEO Duality, identifying a positive relation to greater risk-taking across a battery of sensitivity tests. In further analysis, the study controls for differences in supervisory monitoring levels to examine its impact. Banks led by CEO Chairmen which are subject to lower levels of supervision continue to report a robust association to risk-taking, as before. However, this association dissipates for banks which are subject to heightened supervisory monitoring. These findings indicate that agency costs related to Duality may be moderated by greater regulation. This paper weighs-in on the controversy relating to a single contentious governance structure (i.e., CEO Duality), thus informing boards, regulators and researchers of the need to consider the overall interplay of monitoring mechanisms.
\end{abstract}

Keywords Duality $\cdot$ Monitoring and risk governance $\cdot$ Agency-costs $\cdot$ BHCs $\cdot$ Risk-taking

JEL Classification G3 - G21 - G32

\section{Introduction}

Corporate governance failures contributed to the severity of the financial crisis. While poorly structured incentive schemes, high leverage levels and complex financial products played their role, all too often powerful bank Chief Executive Officers (CEOs) became the recognized face of excessive risk-taking gone wrong. Bank CEOs are well-placed to encourage excessive risk-taking (Fortin et al. 2010; Lu and Boateng 2018). This study examines the potential for agency conflicts in the boardroom which may drive excessive risk-taking. It seeks to contribute to the debate on boardroom structures and their interaction with CEO power (Srivastav and Hagendorff 2016, p 340). It also responds to those

Walter Gontarek

walter.gontarek@gmail.com

1 Cranfield School of Management, Cranfield University, College Road, Cranfield, Wharley End, Bedford MK43 oAL, England 
who call for greater monitoring mechanisms in the context of CEO Duality to curb bank risk-taking (Lu and Boateng 2018).

Governance structure matters (Fama and Jensen 1983; Mehran et al. 2011). Moreover, bank board structure matters relative to non-bank boards because their failure can impose great costs upon society (Pathan 2009). As a result, banks are subject to regulatory oversight (Flannery 1998; Clarke 2004; Macey and O'Hara 2016). Unrestrained CEO power restricts the board's access to risk-based information, reducing independent decision-making (Fama and Jensen 1983). A bank's board retains substantial authority for risk-management (Basel 2015; Macey and O'Hara 2016). Duality (where the CEO also is Chairman) can impede independent monitoring (Jensen 1993; Lasfer 2006). The board also plays a lead role in establishing the bank's risk appetite levels, monitoring capital and liquidity risks, and reviewing CEO performance (Basel 2015). In this study, approximately half of the US Bank Holding Company (BHC) leaders hold both the CEO and Chairman title, thereby carrying responsibility for day-to-day operations and at the same time assuming responsibility for its corporate governance activities.

After the post financial crisis period, a number of changes impacted the governance structures of financial institutions (Dewatripont and Freixas 2012; Dermine 2013; Gontarek 2016). Regulators have introduced a suite of structural changes relating to liquidity, leverage and resolution (Claessens 2014, Tanda 2015). Banks also came under fire from activists, institutional investors, proxy advisory firms and regulators seeking improved corporate governance practices, including the separation of the CEO and Chairman roles (Tonello 2011; FRC 2010; Abels and Martelli 2013). For example, banks were required to explain Duality in their proxy materials in addition to other supervisory measures (Akhigbe et al. 2015).

This paper tests the proposition that agency conflicts (such as weakened board monitoring and informational dissymmetry arising with Duality) results in excessive risk-taking, following Lu and Boateng (2018). Next, the role of regulation is considered more thoroughly by examining the sample for different levels of regulatory intensity. The DoddFrank Act (2010) designated certain BHCs as Systemically Important Financial Institutions (e.g., "SIFIs"), resulting in varying intensity levels of external and internal monitoring (Gao et al. 2013). Since both SIFI and non-SIFI are included in this BHC sample, a unique window exists to observe the impact of Duality upon risk-taking given the varying degrees of regulation. In further analysis, the research reveals that risk-taking continues as before for BHCs not subject to heightened regulation. However, a different picture emerges for $\mathrm{BHCs}$ that are subject to intense external monitoring, where now an insignificant relation is reported between Duality and risk-taking.

This reveals an important finding. Both sets of BHCs practise Duality and face incentives for greater agency conflicts. As noted by Lu and Boateng (2018), Duality may lead to a failure of internal control systems and reduce board monitoring effectiveness. However, BHCs that also are subject to intensive external monitoring appear to successfully curb harmful impacts of agency conflicts leading to excessive BHC risk-taking.

These results underscore the potential for the substitution of monitoring mechanisms to moderate agency costs. The existence of Duality itself may hinder effective board monitoring, but where enhanced monitoring mechanisms are effectively adopted, the impact to risk-taking is no longer significant. Internal and external monitoring mechanisms thus appear to interact (Hardwick et al. 2011; Kim and Lu 2011). Under governance substitution theory, other monitoring features can be substituted to control Duality and thus mitigate harmful agency costs (Rediker and Seth 1995; Krause et al. 2014; Wang et al. 2019). This study is one of the few studies to empirically examine these issues in the post crisis setting (Rediker and Seth 1995; Krause et al. 2014). 
There are several distinctive features of this research. Overall, there is limited research focusing on bank governance structures (including Duality) and risk-taking (Srivastav and Hagendorff 2016; Sun and Liu 2014; Akbar et al. 2017; Lu and Boateng 2018). Although Rediker and Seth (1995) call out for further empirical examination of Duality, little is also known about the interaction monitoring mechanisms (Krause et al. 2014). This is the first study known to the authors concentrating on Duality and BHC risk-taking in the post financial crisis period, exploiting the potential interaction of external supervision and heightened governance as alternative monitoring mechanisms in this setting. The findings are robust to a range of sensitivity analysis, such as reverse causality, omitted variables bias, and alternative measures of CEO power.

\section{Related literature}

\subsection{Literature review}

Corporate governance measures such as Duality and board composition are important indicators of overall governance quality (Tosun and Senbet 2019; Francis et al. 2012; Linck et al. 2008). The bank CEO is a powerful role both in and outside the bank. Among top executives, the bank CEO is endowed to make major decisions ( $\mathrm{Pi}$ and Timme 1993). The existence of Duality confers the dominance of the CEO as the most senior member of top management (Bai and Elyasiani 2013). Combining the CEO Chairman role may be seen as a reward for corporate performance, exceptional contribution, and serve as a retention tool.

At the same time, the board of directors is the primary governance and executive oversight forum (Cornett et al. 2010; Adams 2012). The appointment or dismissal of the CEO is in practice arguably the single most important function of a board. In extreme, it may fire a CEO in cases of misconduct (Fama and Jensen 1983; Charkham 2003). The effectiveness of the board's monitoring role is related to its independence (Finkelstein et al. 2009; Hayes 2013). Applying an agency theory lens, Duality may compromise the efficacy of internal monitoring (Pi and Timme 1993; Chen and Al-Najjar 2012; Tang 2016). Effectively, Duality may usurp the power of the board and diminish its monitoring agenda (Lu and Boateng 2018).

\subsection{Arguments and evidence for and against duality}

There are well argued positions for and against Duality. Arguments in favour of Duality fall under the banner of "benefits of unity of command" hypothesis (Finkelstein and D’Aveni 1994). This position resonates with organizational theory based paradigms such as resource dependence theory (Boyd 1995) and stewardship theory (Donaldson and Davis 1991). These arguments recognise the benefits of prompt implementation of board level decision-making (Jensen and Meckling 1995; Yang and Zhou 2014). Consolidation of power promotes improved managerial coordination (Tang 2016). According to this narrative, the independence of the CEO and Chairman roles is artificial. It duplicates leadership and leads to internal confusion, especially in times of crisis (Larcker and Tayan 2016). As far as boardroom dynamics, influence over the selection of directors by powerful CEO Chairmen can result in fewer conflicts between management and the board. In this framework, Duality can result in improved coordination and even responsive risk management (Smith and Stulz 1985). 
In terms of empirical literature, Byrd et al. (2012) examine governance structures, including Duality, for 130 US savings and loan institutions during the 1980s. They find that firms with non-Duality are significantly more likely to fail than those exhibiting Duality. Berger et al. (2016) and Simpson and Gleason (1999) report a greater incidence of bank failure for US BHCs that separate these two key roles. Pathan (2009) reports evidence of lower risk-taking for a proxy of CEOs power. Mollah and Liljeblom (2016) also construct a similar CEO power index to find a positive impact upon bank quality and performance during the sovereign debt crisis. Grove et al. (2011) find no relation with Duality and loan quality.

Alternatively, there is well-reasoned literature arguing against Duality. One of the primary roles of the board of directors is to monitor the CEO (Li and Roberts 2018). The separation of Chairman and CEO roles is seen as an indicator of good governance, alleviating agency costs and increasing monitoring effectiveness (de Haan and Vlahu 2015; Larcker and Tayan 2016; Allam 2018). The bank Chairman is expected to commit a substantial portion of time on issues facing the bank, promoting informed and critical debate on issues relating to strategy, risk appetite, CEO evaluation and executive remuneration (Walker 2009). Not all good CEOs are necessarily up to this task. Walker (2009) recommends that Chairmen must devote substantial time on board business, facilitating the board's decision-making on executive compensation, succession planning, and the recruitment of new directors. If the role of bank boards is to advise and monitor, then scrutinizing managerial actions for signs of excessive risk-taking is a key governance task (Linck et al. 2008; Lu and Boateng 2018).

The opacity of financial institutions can intensify agency costs (Grove et al. 2011; Sora and Natale 2004). Unfettered CEO power can restrict the board's access to riskbased information, diminishing independent decision-making (de Haan and Vlahu 2015; Pathan 2009; Srivastav and Hagendorff 2016). As such, Duality may curtail monitoring effectiveness (Pathan 2009). Cornett et al. (2009) note that boards relaxed their monitoring as the financial crisis approached, including greater Duality. Given the unique features of banks (Adams and Mehran 2003; John et al. 2016), Duality may result in greater agency conflict, leading to excessive risk-taking (Carty and Weiss 2012). These arguments sit under the banner of "agency costs" hypothesis (Florackis 2008), reflecting agency conflicts associated with greater risk-taking or reduced efficiency.

Empirical evidence also supports the "agency costs" argument. Faleye and Krishnan (2010) find that lending to higher risk customers tends to rise with Duality. Chen and Lin (2016) examine an international sample to find Duality is associated with greater liquidity risks. More recent evidence is reported from Chen and Ebrahim (2018) who examine US banks in the pre-crisis period and find that Duality (along with CEO tenure) is positively related to CEO risk-taking behaviour. Grove et al. (2011) report that Duality is negatively associated with accounting performance measures, consistent to Bhagat et al. (2008). Carty and Weiss (2012) interview US regulators on Duality and observe that supervisors appear to accept the practice but expect other governance mechanisms to curtail agency costs related to Duality. Lewellyn and Muller-Kahle (2012) find a robust relation for CEO power and risk-taking in US firms whereas DeBoskey et al. (2019) find that that Duality is associated with more positive earnings tone announcements. Lu and Boateng (2018) find Duality has a significant impact upon greater bank credit risk levels, proxied by higher Non-Performing Loans (NPLs) and greater Loan Loss Reserves in their UK bank sample. These authors argue Duality and incentives are a major determinant for bank risk-taking. 


\subsection{A public policy issue}

Certain jurisdictions discourage Duality. The Financial Reporting Council in the UK sets out its views: "There should be a clear division of responsibilities at the head of the company between the running of the board and the executive responsibility for the running of the company's business. No one individual should have unfettered powers of decision" (FRC 2010). The Canadian regulator is un-ambiguous with respect to Duality: "The role of the Chair should be separated from the CEO as this is critical for maintaining the Board's independence, as well as its ability to execute its mandate effectively" (OSFI 2018). Likewise, the view is equally clear for Irish and Australian regulated financial institutions (Central Bank of Ireland 2015; APRA 2018). Few banks in Europe exercise Duality (Andersson and Nestor 2018). The European Banking Association (EBA) indicated that the CEO and Chairman should not be the same person unless the board determines it is in the best interests of the enterprise (European Banking Association 2011).

In the US, the Securities and Exchange Commission (SEC) considered the role that Duality may have had in the driving financial crisis (Abels and Martelli 2013). Investors sought to split the joint CEO Chairman role at a number of US BHCs, in an effort to reduce conflicts of interest (Krause et al. 2014). Investors and their advisors such as ISS argued for a split of the CEO and Chairman role at JP Morgan Chase \& Co., indicating "Unchecked risk-taking and oversight failures have cost J.P. Morgan \& Co. more than \$6 billion in losses" (AFSCME Pension Fund 2013). US firms that received federal assistance under the 2008 Troubled Asset Relief Program (TARP) were at first required to separate the CEO and Chairman roles (Yang and Zhou 2014). The Dodd-Frank Act of 2010 however relaxed this approach, requiring firms to only comply or explain (Brown 2010).

While adopting the same zero tolerance of Duality followed in Europe and Canada, US supervisors indicate: "When the board chair and the CEO are different individuals, having the separate roles may help insure a more appropriate balance of power between board and management" (OCC Bank Director Handbook 2016). Notwithstanding this debate, empirical evidence on the impact of board level features upon bank risk-taking remains unsettled (Srivastav and Hagendorff 2016; Lu and Boateng 2018).

\section{Data and variables}

\subsection{The data}

Panel data employed in this study, combining both time-series and cross-sectional data (Minton et al. 2014; Adams and Jiang 2015). The data is comprised of slowly changing Duality, corporate governance and ownership data, suggesting the use of pooled ordinary least squares (Zhou 2001). For convenience, "Appendix 1" provides the empirical definition of all variables used in this study.

\subsection{Sample selection}

The sample consists of the 140 largest BHCs found on the Federal Reserve's website. ${ }^{1}$ Data availability on US BHCs makes this a prime sample to study governance and regulatory

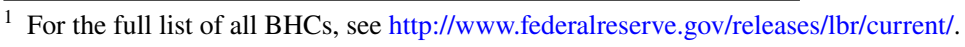


Table 1 The variables: descriptive statistics (full sample)

\begin{tabular}{lcccccc}
\hline & $N$ & Mean & St.Dev & Median & Min & Max \\
\hline Efficiency ratio & 796 & 63.56 & 13.807 & 63.466 & 28.941 & 250.721 \\
NPLTL & 777 & 0.869 & 0.731 & 0.711 & 0.01 & 7.731 \\
Tier1 & 795 & 13.495 & 3.989 & 12.6 & 7.5 & 51.9 \\
Tail risk & 786 & -19.967 & 23.877 & -13.376 & -221.74 & 4.567 \\
Z-score & 768 & 0.829 & 8.661 & 1.097 & -150.179 & 77.905 \\
Duality & 834 & 0.498 & 0.5 & 0 & 0 & 1 \\
CEO tenure & 797 & 2.134 & 0.907 & 2.197 & 0 & 3.829 \\
CEO shareholding & 783 & 16.076 & 1.511 & 15.992 & 11.215 & 20.795 \\
TARP & 572 & 5.674 & 1.961 & 5.215 & 1.609 & 10.754 \\
Board size & 828 & 11.693 & 3.604 & 12 & 0 & 32 \\
BHC size & 814 & 9.616 & 1.518 & 9.17 & 6.712 & 14.745 \\
Deposits & 810 & 74.675 & 10.963 & 77.5 & 22.004 & 90.591 \\
Total Loans & 809 & 64.952 & 15.735 & 68.49 & 5.529 & 96.167 \\
Board non-insider & 806 & 28.345 & 40.661 & 0.917 & 0.167 & 95 \\
Risk committee & 834 & 0.691 & 0.463 & 1 & 0 & 1 \\
Risk appetite & 834 & 0.253 & 0.435 & 0 & 0 & 1 \\
CRO centrality & 682 & 0.243 & 0.284 & 0.246 & 0 & 4.348 \\
CRO tenure & 699 & 8.651 & 8.428 & 6 & 0 & 41 \\
\hline
\end{tabular}

issues (Huang et al. 2017). The sample represents some $70 \%$ of US banking assets for a notional sum of $\$ 11$ trillion. The sample reports for the period 2012 to 2017, inclusive for US BHCs (not operations of foreign banks based outside the USA). The list of BHCs is found in "Appendix 2".

\subsection{Dependent variables}

This study's dependent variables include typical bank risk-taking measures Non-Performing Loans (NPLs), Tier 1 Capital, Tail-Risk and the Z-score. The Efficiency Ratio is also included as a dependent variable, as noted below. The corporate governance data comes from BoardEx (BoardEx 2016) whereas BHC financial data is collected from Bloomberg, or as otherwise noted. Table 1 details these variable definitions.

Following Ellul and Yerramilli (2013), NPLs and Tail Risk are used as outcome variables. NPLs are an overall indicator of credit portfolio quality (OCC Director's Handbook 2016; Keffala 2017). Lu and Boateng (2018) argue that NPLs are a proxy for the effectiveness of bank credit risk management. Higher NPL rates reflect riskier lending practices (Nakano and Nguyen 2012). BHC Tail Risk (Ellul and Yerramilli 2013; Kanas and Zervopoulos 2019) is the negative of the average return on the BHC's stock over the 5\% worst return days annually. BHCs with an independent and effective risk management function should have lower enterprise-wide tail risk (Kashyap et al. 2008). Improved management of Tail Risk can mitigate the risk of large unexpected losses and mitigate systemic risks (SSG 2008, 2009; Ellul and Yerramilli 2013). Tail Risk is closely related to the Marginal Expected Shortfall Measure (MES) used elsewhere in the literature to proxy the propensity 
to experience a capital shortfall in stress conditions (Acharya et al. 2011; Iqbal and Vähämaa 2018). (Kanas and Zervopoulos 2019) describe this measure as a systemic fragility metric.

Capital ratios are an important predictor of bank risk (Hogan et al. 2017). ${ }^{2}$ Capital serves as a buffer for risks that may otherwise cause distress and even failure (Beltratti and Stulz 2012). Well capitalized banks improve the prospects of survival (Swamy 2018). Capital is particularly important for crisis periods to compensate for large, unexpected losses (Berger and Bouwman 2013). Tier 1 Capital is used in this study (Minton et al. 2014; Fahlenbrach and Stulz 2011). As noted by Iqbal and Vähämaa (2018), capital is the main variable of interest to regulatory authorities. Next, the Z-score (Altman 1968) is also used in this study, following Laeven and Levine (2009), (Radic et al. 2012), and Nakano and Nguyen (2012).

Bank efficiency may be related to risk-taking incentives (Silva et al. 2016). This line of reasoning is that inefficient banks face profit pressures, thus more exposed to excessive risk-taking incentives to achieve short-term revenue targets ( $\mathrm{Lu}$ and Boateng 2018). Inefficient banks also face incentives for greater risk-taking (Fiordelisi et al. 2011). The Efficiency Ratio is a practical measure used in everyday banking, essentially indicating the fraction of one dollar required to produce one dollar of revenue excluding funding costs, so lower ratio values indicate more efficient banks.

\subsection{Key explanatory variables}

CEO characteristics are next discussed. Duality is measured as a dummy variable of 1 if the same person holds the title of BHC CEO and Chairman in a given year, following Zagorchev and Gao (2015). Next, CEO Tenure is measured as the number of years that the CEO is on the board of directors. New board members may feel intimidated by an established CEO (Bebchuk et al. 2002; Byrd and Cooperman 2010). The explanatory variables also cater for CEO incentives. Bank CEOs can generate significant wealth in holding shares or experience wealth losses (Fahlenbrach and Stulz 2011). CEO Ownership is calculated as the log of total USD holdings of BHC equity held by the CEO for each year. This explanatory variable reflects important incentives to bank CEOs to limit the bank's risk exposures, following Chung and Pruitt (1995) and Onali et al. (2016). Chung and Pruitt (1996), Bai and Elyasiani (2013), Onali et al. (2016) and Bouwens and Verriest (2014). ${ }^{3}$ According to Aebi et al. (2012) who similarly measure CEO Ownership, this explanatory variable serves as a proxy for incentives relating bank CEOs to maximize value and limit the bank's risk exposures.

The governance variables relate to the strength of the monitoring function (Spong and Sullivan 2007). Board Size is measured by the number of total directors on the BHC board of

\footnotetext{
${ }^{2}$ See Beltratti \& Paladino (2015) for an empirical analysis of this subject who argue that in fact banks with greater capital levels enjoy a higher residual income, higher return on capital and a lower cost of capital.

3 This measure of the USD amount of BHC equity held for each year is used versus the alternative of the percentage of total share measure because banks with larger percentage ownership are in general smaller banks with smaller capitalizations, and thus smaller dollar amounts are actually at risk. Conversely, when a manager of a larger BHC owns only a small percent of shares, the corresponding dollar amount may be very high for BHCs with higher capitalization levels exhibiting a strong alignment of interest and incentives as noted by Bouwens and Verriest (2014) page 24 and Aebi et al. (2012) page 3217. Thanks to Gabriele Sabato for his input relating to the specification of this variable.
} 
directors, following de Andres and Vallelado (2008). While large boards can draw from a vast pool of expertise, others argue that they may face free-rider or other practical challenges (Jensen 1993). Key differences in BHC business models are catered for with control variables. BHC Size is employed in this study following Akhigbe et al. (2016) and Zagorchev and Gao (2015). The size of a bank denotes the potential scale, breadth of products and complexity. BHC Size is calculated as the log value of BHC assets as collected from the US Federal Reserve website. ${ }^{4}$ The amount of total loans (Total Loans) is measured as the ratio of total-loans to total-assets (Switzer and Wang 2013; Kupeic and Lee (2012). The extent of loans can vary depending upon business model differences. Banks mainly use deposits to finance loan growth (Mamun and Hassan 2016; Egly et al. 2018). The ratio of deposits-to-total assets (Deposits) reflects the extent to which secure funding may originate from depositors (Minton et al. 2014). Lastly, the receipt of bailout funds indicates greater moral hazard incentives related to government support (Black and Hazelwood 2012). Duchin and Sosyura (2014) report that bailed out banks originated riskier loans and securities after receiving government funding. Participation in the Troubled Asset Relief Plan (TARP) is included as a control variable.

The $\$ 700$ billion of TARP funds issued were used to purchase preferred stock and stock warrants across a total of 707 financial institutions including commercial banks Gangopadhyay et al. (2018). The USD amount of TARP funds received by each BHC is collected from the ProPublica website following Shah et al. (2017); (Minton et al. 2014). ${ }^{5}$

\section{Empirical analysis}

\subsection{Descriptive statistics}

Summary statistics for the key risk and explanatory variables used in the sample are presented in Table 1. Starting with the dependent variables, the Efficiency Ratio is reported at 64\%, versus 66\% reported in Radic et al. (2012) and Mamatzakis and Bermpei (2015) and $71 \%$ in Lu and Boateng (2018) for their UK sample. Non-performing loans (NPLTLs) are reported at 0.87 . Goetz (2018) reports a bank NPL ratio of 1.51 for the 1976 to 2006 period. Non-performing loans are reported by Akhigbe et al. (2015) at 1.73 in their small bank sample. Tier 1 capital levels are reported at $13.5 \%$ in this study, versus $12.4 \%$ in Leventis and Dimitropoulos (2012) and $12.7 \%$ in Iqbal and Vähämaa (2018). Tail Risk is reported at-19.9 versus 4.9 in Ellul and Yerramilli (2013) for the pre-crisis period and 14.3 reported in Lingel and Sheedy (2012). The mean value of the Z-score is 0.83 .

In terms of CEO related explanatory variables used, Duality is reported at 50\%, compared to $48.6 \%$ in Cornett et al. (2016) and 61\% in Faleye et al. (2017). The mean value of the market value of CEO shareholding ( $\log$ ) is \$16.1 million, compared to \$26.0 million in Bai and Elyasiani (2013). Board size in the full sample is 11.6, versus 8.5 in Yang and Zhao (2014). Next, business level variables are examined. BHC Size is $\$ 75.5$ billion (log value $\$ 9.6$ billion), versus log values of $\$ 10.1$ in Shah et al. (2017), $\$ 7.9$ billion in Chen et al. (2018) and $\$ 8.28$ billion in Kozubovska (2017). The mean value of Total Loans is $65 \%$, versus $62 \%$ in Iqbal and Vähämaa (2018). The mean value of Deposits is $74.6 \%$, compared to $73.9 \%$ in Aebi et al. (2012) and 66.97\% in Akhigbe et al. (2015).

\footnotetext{
${ }^{4}$ See (http://www.federalreserve.gov/releases/lbr/current/).

${ }^{5}$ TARP amounts are collected from the ProPublica website at https://projects.propublica.org/bailout/list. Over 440 financial institutions in total (AIG and others) received TARP payments between starting November 2007 until January 2009.
} 
Governance variables are next reported. CRO Tenure, the number of years a CRO holds this position, is reported at 8.6-years. Risk committees report a mean value of $69 \%$, compared to 59.6\% in Iselin (2016). Following Dupire and Slagmulder (2018), Risk Committee Charters are collected in this study (on-line) to note the adoption of a risk appetite framework. BHCs which formally approve Risk Appetite arrangements are assigned a dummy value of one, following Gontarek and Belghitar (2018). In this study, Risk Appetite is adopted across $25 \%$ of the sample, versus $46 \%$ in Dupire and Slagmulder (2018). The mean value of the CRO Centrality variable in this study is $24.3 \%$, versus $31.3 \%$ reported in Ellul and Yerramilli (2013).

\subsection{Correlation analysis for key variables}

Table 2 reports the pairwise correlation analysis for the variables used in the baseline analysis. Turning attention first to BHC outcomes, the Efficiency Ratio is positively related and significantly correlated to NPLs and Tier 1, consistent with the extant literature. NPLs are negatively related to CEO Ownership and CEO Tenure. Tier 1 capital exhibits a significant negative relation to BHC Size, as reported in Ellul and Yerramilli (2013) and Battaglia and Gallo (2015). Tail Risk is negatively significantly related to Duality, CEO Ownership, and CEO Tenure suggesting here an inverse relationship. Duality is positively related and significant with CEO Ownership and CEO Tenure, as expected. Duality is positively correlated with the Efficiency Ratio, consistent with Lu and Boateng (2018).

\subsection{Multi-variate estimations-baseline analysis}

Table 3 shows the baseline determinants of BHC risk-taking. The initial examination begins by estimating a series of pooled ordinary least squares (OLS) panel regressions. The results are presented in each column headed by the relevant dependent variable, for both contemporaneous and lagged examinations.

Turning to the first model in Table 3 to observe the determinants of NPLs, the coefficient for Duality is positive and records a value of.178, indicating on average banks with the combined CEO Chairman role experience. 178 higher in NPLs. The statistical significance of this relation is one per cent, compared to the ten per cent significant positive relation between Duality and NPLs observed in Lu and Boateng (2018). Duality is one per cent positively related to Tier 1 levels in column 2, with a coefficient value suggesting on average BHCs with dual governance structures of CEO and the Chairman carries a further 59 basis points of capital. Table 3 column 3 reports the determinants of Tail Risk. A positive and ten per cent significant relation of Duality is reported. In the next column for the Z-score, Duality reports an insignificant coefficient value.

Lastly, the analysis turns to the Efficiency Ratio. Duality is positively related to the Efficiency Ratio, indicating BHCs with dual CEO Chairman roles are less efficient, on average. Recalling the bad management hypothesis noted in Fiordelisi et al. (2011), we note that lower level of bank efficiency can drive greater bank risk-taking incentives, over time. $\mathrm{Lu}$ and Boateng (2018) note that greater bank efficiency levels have a positive influence relative to overall credit risk levels.

Next, a series of lagged examinations of the same baseline model is recorded. The primary purpose of lagged examinations is to investigate the influence of the Duality upon subsequent BHC risk-taking (Li 2016; Faleye et al. 2011). Table 3 columns 6-10 records 


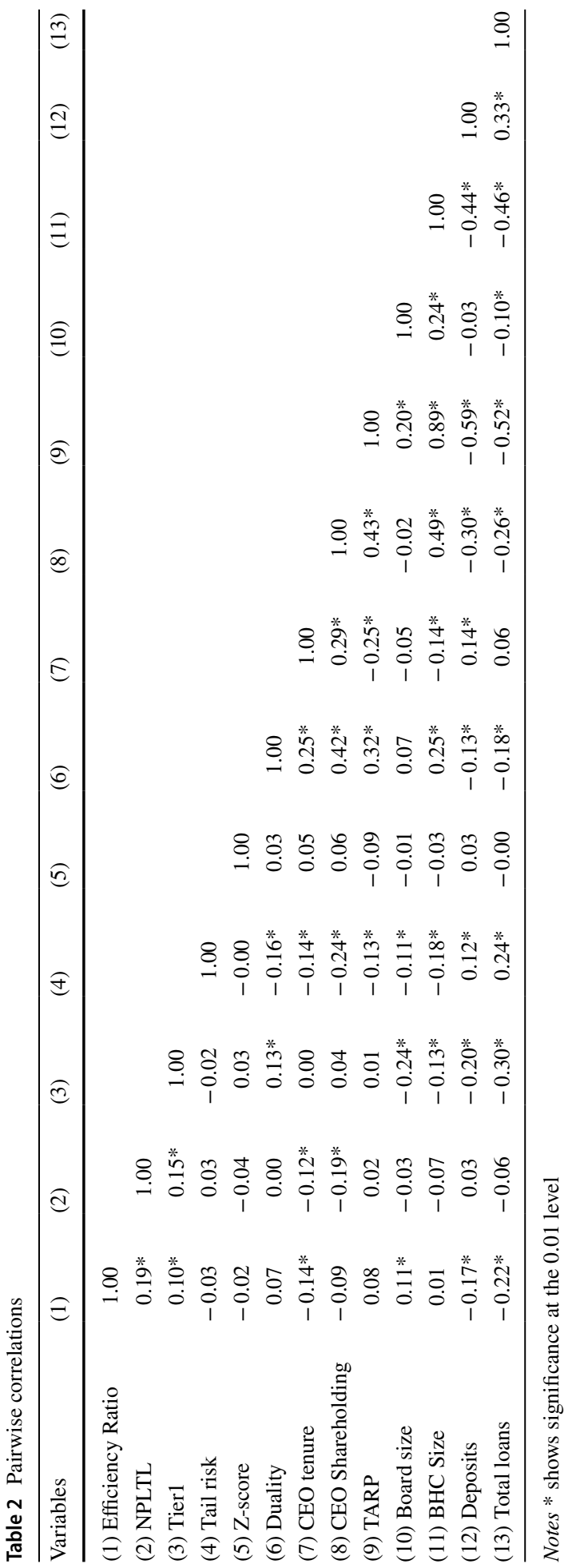




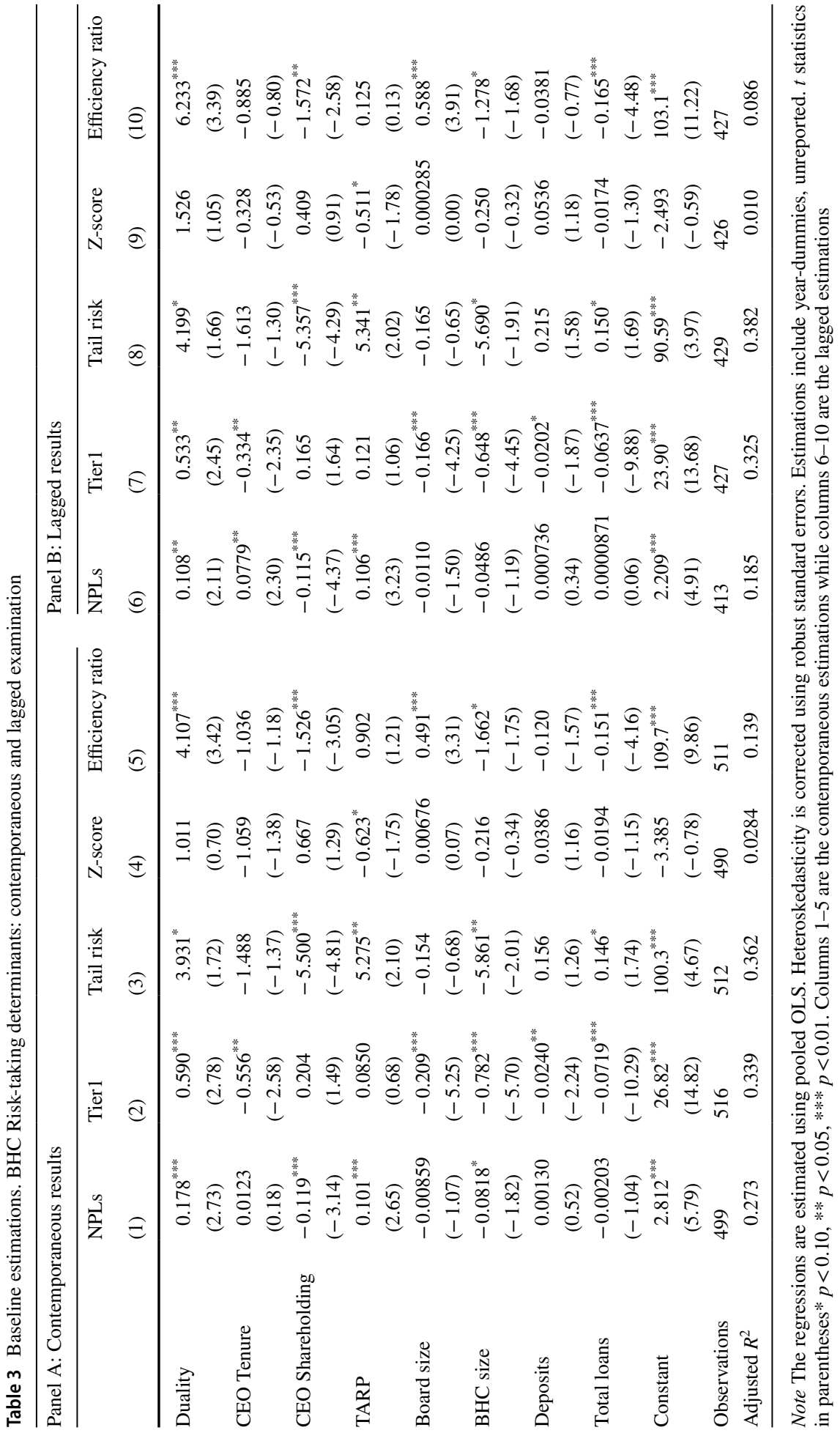


the results of these examinations. A series of lagged tests are conducted where all explanatory variables are lagged for each dependent variable, following Vallascas et al. (2017); Boone et al. (2007); Faleye (2015) and Li and Roberts (2018) who employ this technique to reduce endogeneity and simultaneity biases.

Staring with Model 6, the impact of Duality upon NPLs is observed and continues to exhibit a positive and five per cent significant relationship. Next, the results for the determinants of Tier 1 are examined. Duality remains positively related and significant in Model 7 of Table 3 to Tier 1 . The lagged determinants of Tail Risk are next reported in Table 3 column 8. Model 8 reports a ten per cent significant positive association here, indicating that BHCs with Duality as a governance structure exhibit positive Tail Risk. The Z-score is not significant in any of these examinations but reports a negative coefficient value. Efficiency is reviewed next in Table 3, Model 10. Duality is again one per cent positively related to the Efficiency Ratio for both models, indicating that BHCs managed with this governance structure are less efficient. In both contemporaneous and lagged examinations, Duality is associated with greater NPLs, positive Tail Risk, carry greater levels of capital to support risk-taking and are less efficient.

\section{Sensitivity analysis}

In this section a range of sensitivity checks are conducted on the determinants of risk-taking measures to ensure the validity of the foregoing results. First, the issue of endogeneity is addressed (Chen et al. 2008). Second, an alternative measure of CEO power based on an index is employed. Third, the impact of enhanced monitoring is examined by splitting the sample into BHCs subject to greater and lower levels of monitoring. Finally, to further mitigate the issue of omitted variable bias, a further suite of governance mechanisms is added to the baseline regressions.

\subsection{Endogeneity}

It is generally held that endogeneity can plague corporate governance studies, leading to bias and inconsistent results (Hermalin and Weisbach 2003; Berger et al. 2016). There are two possible causes of endogeneity: reverse causality (simultaneity) and omitted variables. Turning first to reverse causality, there is a possibility that the choice of governance structure (in this case Duality) is determined by excessive BHC risk-taking levels. A plausible explanation is therefore that higher risk-taking activity could drive boards to consolidate power in the hands of one individual in order to realise the benefits of coordination and improved communication (Tang 2016). While the earlier lagged analysis may somewhat mitigate these concerns, it is acknowledged that Duality and the risk measures may still be endogenously determined.

To address the issue of endogeneity emanating from reverse causality, further analyses is carried out on the sample and reported in Tables 4, 5 and 6. First, inspired by Faleye et al. (2011) and Coles et al. (2008), a new series of estimations are conducted with Duality measured years earlier than the sample time period (in this case on the first day of 2008). This approach brings two advantages. It somewhat mitigates some of the effects of reverse causality by measuring the variable of interest years before the study period and also captures this governance practice before the global financial crisis 


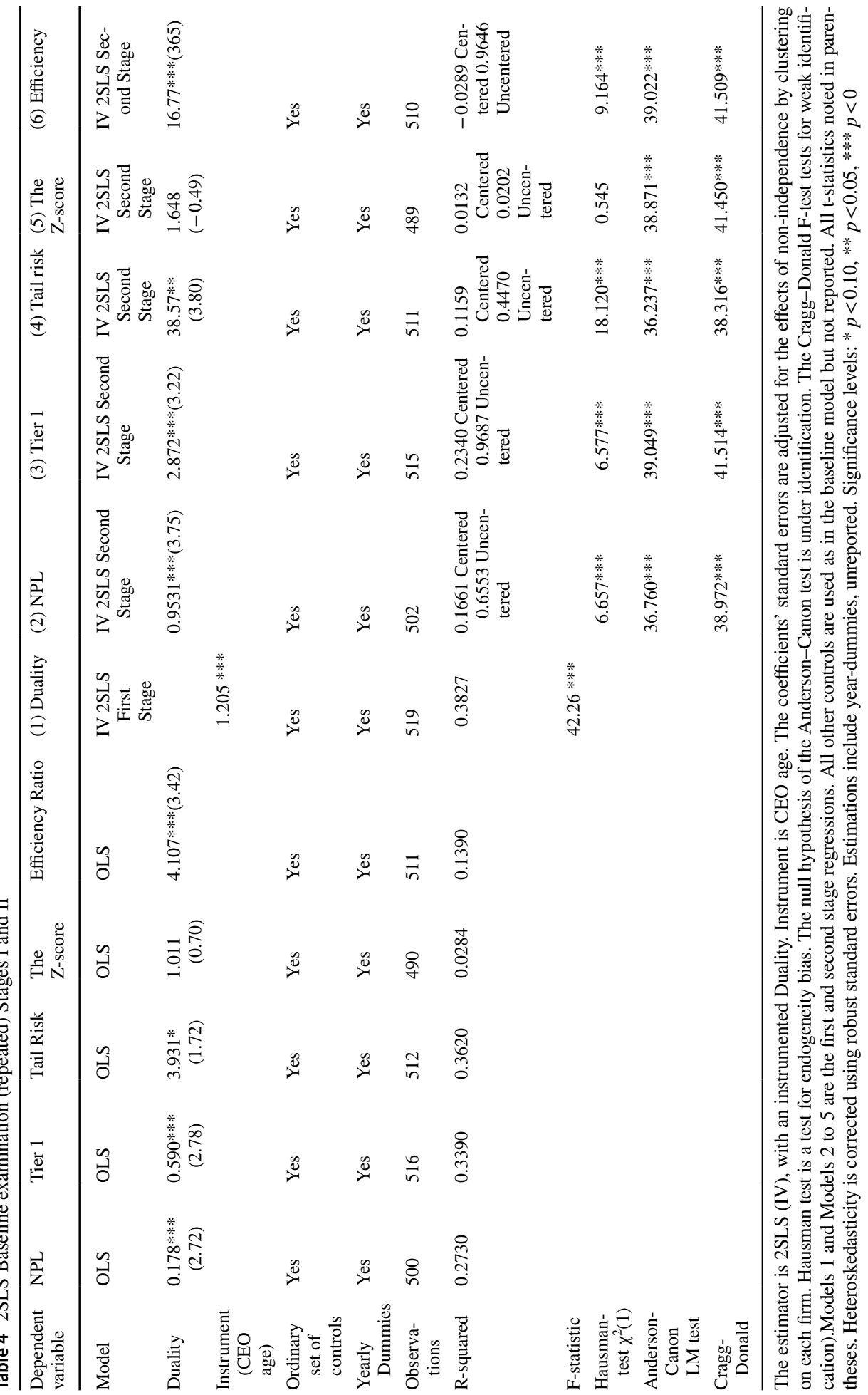


erupted and policy changes were ushered in by regulators. This new variable, Duality 2008 , replaces the contemporaneously-measured variable used in the earlier estimations. In unreported findings to conserve space, Duality 2008 holds a qualitatively similar relation to BHC risk-taking. Duality 2008 as the key variable of interest is five per cent significant and positively related to NPLs and Tier 1 while reporting a one per cent significant and positive relation to Tail Risk.

Second, the issue of reverse causality is addressed by reporting the results based on single equation instrumental variable estimation as well as results based on simultaneous equation framework. Instrumental Variable class estimators are commonly used to deal with endogeneity problems including reverse causality (Larcker and Rusticus 2009; Lee et al. 2016a, b). As noted by Adams and Mehran (2012), the instrument used in this analysis should correlate with Duality but be uncorrelated with risk-taking except through variables already in the regression. Identifying valid instruments are never an easy task (Antonakis et al. 2010).

Fortunately, the literature guides the choice of instrument for Duality. Following Yang and Zhou (2014) who also examine Duality, the choice of instrument employed in this study is the natural logarithm of CEO Age. As noted, Linck et al. (2008), the combined CEO Chairman role is significantly and robustly related to CEO Age. However, it is not obvious that CEO Age is related to the dependent variables used in this study. Skala and Weill (2015) examine CEO Age versus outcome variables bank Tier 1 capital ratio and NPLs (as used in this study), finding little relation to these measures. Ho et al. (2016) use CEO Age as an instrument for CEO overconfidence but should have no relation upon bank lending and leverage/Tier 1. CEO Age has also been employed as an instrument by Cornett et al. (2009), Palia (2001) and Brick et al. (2006) in other bank corporate governance research.

Table 4 reports the results based 2SLS across the first 5 dependent variables. A test is initially carried out to determine whether the estimated variable Duality is endogenous. Except for the dependent variable $\mathrm{Z}$ score, the Hausman test provides significant evidence of an endogeneity bias at the 5\% level between all other bank risk measures and Duality, suggesting the latter requires instrumentation. The Anderson Canon test is significant and indicates that the equation is identified. The Cragg-Donald F-statistic is greater than the critical value provided by Stock and Yogo (2005), suggesting that the null hypothesis of CEO age as a weak instrument can be rejected.

Table 4 adopts the instrumental variable reporting set-up used by Berger et al. (2016) for ease of reporting, including the initial OLS results reported earlier before presenting stage one and stage two results of the 2SLS estimation across Model (1) and Model (2). In Model (1) of Table 4, the first stage results of the 2SLS estimation is presented, indicating that the instrument, CEO Age, is positively and significantly related to Duality at the one per cent level. The second stage of the 2SLS analysis validate the earlier findings observed - Duality is positively and significantly related with higher risk-taking as before. Duality is positive and one-per cent significantly related to NPLs, Tier 1, and the Efficiency Ratio. Duality is also positive and five-per cent significantly related to Tail Risk in the second stage of the 2SLS estimations, recalling that Tail Risk is a particularly potent form of risk profile for BHCs, and difficult to observe by regulators with potentially disastrous consequences (Ellul 2015).

Moreover, the instrumental variable coefficient values in columns 2-6 are also consistently larger than the previously reported values in the OLS coefficient estimates from Table 3. Larger coefficient values observed in the instrumental variables estimations validates a more powerful prediction models when compared to the earlier un-instrumented analysis (Larcker and Rusticus 2010; Berger et al. 2016; Elamer et al. 2018). The second 
Table 5 3SLS

\begin{tabular}{|c|c|c|c|c|c|}
\hline & 1. NPLs & 2. Tier & 3. Tail risk & 4. Z-score & 5. Efficiency ratio \\
\hline Duality & $\begin{array}{l}0.876^{* * *} \\
(3.28)\end{array}$ & $\begin{array}{l}1.758^{* *} \\
(1.98)\end{array}$ & $\begin{array}{l}40.32^{* * *} \\
(3.21)\end{array}$ & $\begin{array}{l}1.664 \\
(0.51)\end{array}$ & $\begin{array}{l}13.84^{* * *} \\
(2.99)\end{array}$ \\
\hline CEO tenure & $\begin{array}{l}-0.0585 \\
(-1.19)\end{array}$ & $\begin{array}{l}-0.589^{* * *} \\
(-3.90)\end{array}$ & $\begin{array}{l}-5.433^{* *} \\
(-2.49)\end{array}$ & $\begin{array}{l}-0.993^{*} \\
(-1.81)\end{array}$ & $\begin{array}{l}-1.602^{* *} \\
(-1.97)\end{array}$ \\
\hline CEO shareholding & $\begin{array}{l}-0.247^{\text {**** }} \\
(-5.22)\end{array}$ & $\begin{array}{c}0.253^{*} \\
(1.70)\end{array}$ & $\begin{array}{l}-10.01^{* * *} \\
(-4.51)\end{array}$ & $\begin{array}{l}-0.641 \\
(-1.14)\end{array}$ & $\begin{array}{l}-1.981^{* *} \\
(-2.50)\end{array}$ \\
\hline TARP & $\begin{array}{l}0.0669 \\
(1.47)\end{array}$ & $\begin{array}{r}0.230 \\
(1.61)\end{array}$ & $\begin{array}{l}-3.378^{*} \\
(-1.70)\end{array}$ & $\begin{array}{l}-1.765^{\text {*** }} \\
(-3.08)\end{array}$ & $\begin{array}{c}1.118 \\
(1.51)\end{array}$ \\
\hline Board size & $\begin{array}{l}-0.00787 \\
(-0.71)\end{array}$ & $\begin{array}{l}-0.204^{* * *} \\
(-5.93)\end{array}$ & $\begin{array}{l}-0.333 \\
(-0.71)\end{array}$ & $\begin{array}{l}0.0207 \\
(0.18)\end{array}$ & $\begin{array}{l}0.433^{* *} \\
(2.38)\end{array}$ \\
\hline $\mathrm{BHC}$ size & $\begin{array}{l}-0.101^{* *} \\
(-2.02)\end{array}$ & $\begin{array}{l}-0.862^{* * *} \\
(-5.72)\end{array}$ & $\begin{array}{c}1.681 \\
(0.81)\end{array}$ & $\begin{array}{r}0.780 \\
(1.39)\end{array}$ & $\begin{array}{l}-1.999^{* *} \\
(-2.54)\end{array}$ \\
\hline Deposits & $\begin{array}{l}-0.000612 \\
(-0.16)\end{array}$ & $\begin{array}{l}-0.0190^{*} \\
(-1.71)\end{array}$ & $\begin{array}{l}-0.0893 \\
(-0.57)\end{array}$ & $\begin{array}{l}-0.00513 \\
(-0.13)\end{array}$ & $\begin{array}{l}-0.125^{* *} \\
(-2.07)\end{array}$ \\
\hline Total loans & $\begin{array}{l}-0.00364 \\
(-1.40)\end{array}$ & $\begin{array}{l}-0.0756^{* * *} \\
(-10.13)\end{array}$ & $\begin{array}{l}0.334^{\text {*** }} \\
(3.22)\end{array}$ & $\begin{array}{l}0.0235 \\
(0.93)\end{array}$ & $\begin{array}{l}-0.177^{\text {*** }} \\
(-4.47)\end{array}$ \\
\hline Constant & $\begin{array}{l}5.544^{* * * *} \\
(7.08)\end{array}$ & $\begin{array}{l}25.21^{* * *} \\
(10.36)\end{array}$ & $\begin{array}{c}123.7^{* * * *} \\
(3.47)\end{array}$ & $\begin{array}{l}13.42 \\
(1.56)\end{array}$ & $\begin{array}{c}120.2^{* * *} \\
(9.12)\end{array}$ \\
\hline NPLTL & $\begin{array}{l}\text { Duality } \\
-0.356^{* * *} \\
(-3.84)\end{array}$ & Duality & Duality & Duality & Duality \\
\hline Tier 1 & & $\begin{array}{l}0.0288^{* *} \\
(2.19)\end{array}$ & & & \\
\hline Tail Risk & & & $\begin{array}{l}-0.0206^{\text {*** }} \\
(-6.99)\end{array}$ & & \\
\hline Z-score & & & & $\begin{array}{l}-0.0307 \\
(-1.53)\end{array}$ & \\
\hline Efficiency ratio & & & & & $\begin{array}{l}-0.00115 \\
(-0.25)\end{array}$ \\
\hline CEO Age (Instrument) & $\begin{array}{l}1.799^{* * *} \\
(7.96)\end{array}$ & $\begin{array}{l}1.677^{\text {*** }} \\
(8.56)\end{array}$ & $\begin{array}{l}2.080^{* * *} \\
(7.43)\end{array}$ & $\begin{array}{l}1.655^{* * *} \\
(7.00)\end{array}$ & $\begin{array}{l}1.664^{* * *} \\
(8.39)\end{array}$ \\
\hline Constant & $\begin{array}{l}-6.514^{* * * *} \\
(-7.06)\end{array}$ & $\begin{array}{l}-6.687^{* * *} \\
(-8.13)\end{array}$ & $\begin{array}{l}-8.395^{\text {*** }} \\
(-7.25)\end{array}$ & $\begin{array}{l}-6.208^{* * *} \\
(-6.43)\end{array}$ & $\begin{array}{l}-6.192^{* * *} \\
(-7.48)\end{array}$ \\
\hline Observations & 498 & 515 & 511 & 489 & 510 \\
\hline
\end{tabular}

The estimator is three-stage least squares. All $t$-statistics noted in parentheses. Heteroskedasticity is corrected using robust standard errors. Estimations include year-dummies, unreported. Significance levels: * $p<0.10, * * p<0.05, * * * p<0$

stage regression indicates that Duality is significantly related with greater risk-taking, consistent with the earlier examinations reported in this study, providing further evidence of the robustness of this relationship.

In addition to reporting results based on single equation instrumental variable estimation, the relation between bank risk-taking measures and Duality in a simultaneous equation is now modelled, using three-stage least squares (3SLS), where the disturbance terms 
Table 6 Dynamic panel data specification of BHC Risk-Taking Determinants

\begin{tabular}{|c|c|c|c|c|c|}
\hline & NPLs & Tier1 & Tail Risk & Z-score & Efficiency ratio \\
\hline NPLTL $_{t-1}$ & $\begin{array}{l}0.423^{* * *} \\
(6.96)\end{array}$ & & & & \\
\hline Tier $1_{t-1}$ & & $\begin{array}{l}0.0467 \\
(0.20)\end{array}$ & & & \\
\hline Tail risk $_{\mathrm{t}-1}$ & & & $\begin{array}{l}0.581^{* * * *} \\
(11.53)\end{array}$ & & \\
\hline Z-score $_{\mathrm{t}-1}$ & & & & $\begin{array}{l}-0.0209 \\
(-0.09)\end{array}$ & \\
\hline Efficiency ratio $_{\mathrm{t}-1}$ & & & & & $\begin{array}{l}0.514^{* *} \\
(1.73)\end{array}$ \\
\hline Duality & $\begin{array}{l}0.0969^{* *} \\
(2.42)\end{array}$ & $\begin{array}{c}0.490^{*} \\
(1.73)\end{array}$ & $\begin{array}{l}-4.140 \\
(-1.55)\end{array}$ & $\begin{array}{l}3.318^{* * *} \\
(2.83)\end{array}$ & $\begin{array}{l}3.369^{* *} \\
(2.59)\end{array}$ \\
\hline CEO tenure & $\begin{array}{l}-0.0282 \\
(-1.21)\end{array}$ & $\begin{array}{l}-0.349^{* *} \\
(-1.98)\end{array}$ & $\begin{array}{c}1.090 \\
(0.66)\end{array}$ & $\begin{array}{l}-1.065 \\
(-1.44)\end{array}$ & $\begin{array}{l}-0.0154 \\
(-0.02)\end{array}$ \\
\hline CEO shareholding & $\begin{array}{l}-0.0297^{*} \\
(-1.74)\end{array}$ & $\begin{array}{l}0.0566 \\
(0.69)\end{array}$ & $\begin{array}{l}-0.315 \\
(-0.26)\end{array}$ & $\begin{array}{c}0.526 \\
(0.94)\end{array}$ & $\begin{array}{l}-1.353^{\text {**** }} \\
(-2.79)\end{array}$ \\
\hline TARP & $\begin{array}{l}0.0716^{* * *} \\
(3.50)\end{array}$ & $\begin{array}{c}0.122 \\
(1.39)\end{array}$ & $\begin{array}{l}-1.842 \\
(-1.36)\end{array}$ & $\begin{array}{l}-1.286^{* *} \\
(-2.21)\end{array}$ & $\begin{array}{c}0.289 \\
(0.52)\end{array}$ \\
\hline Board size & $\begin{array}{l}0.00277 \\
(0.48)\end{array}$ & $\begin{array}{l}-0.205^{* * *} \\
(-3.16)\end{array}$ & $\begin{array}{l}-0.175 \\
(-0.46)\end{array}$ & $\begin{array}{l}-0.0818 \\
(-0.53)\end{array}$ & $\begin{array}{r}0.238 \\
(1.39)\end{array}$ \\
\hline $\mathrm{BHC}$ size & $\begin{array}{l}-0.0755^{\text {**** }} \\
(-2.69)\end{array}$ & $\begin{array}{l}-0.648^{* *} \\
(-2.57)\end{array}$ & $\begin{array}{l}3.697^{* *} \\
(2.18)\end{array}$ & $\begin{array}{c}0.393 \\
(0.54)\end{array}$ & $\begin{array}{l}-0.479 \\
(-0.54)\end{array}$ \\
\hline Deposits & $\begin{array}{l}0.00164 \\
(0.90)\end{array}$ & $\begin{array}{l}-0.0245^{* *} \\
(-2.04)\end{array}$ & $\begin{array}{c}0.114 \\
(0.91)\end{array}$ & $\begin{array}{l}0.0648 \\
(1.24)\end{array}$ & $\begin{array}{l}0.0314 \\
(0.48)\end{array}$ \\
\hline Total loans & $\begin{array}{l}-0.00179 \\
(-1.31)\end{array}$ & $\begin{array}{l}-0.0665^{* * *} \\
(-3.70)\end{array}$ & $\begin{array}{r}0.107 \\
(1.32)\end{array}$ & $\begin{array}{l}-0.0173 \\
(-0.54)\end{array}$ & $\begin{array}{l}-0.0993^{*} \\
(-1.91)\end{array}$ \\
\hline Constant & $\begin{array}{l}1.153^{* * *} \\
(2.93)\end{array}$ & $\begin{array}{l}26.12^{* * *} \\
(3.51)\end{array}$ & $\begin{array}{l}-41.13^{* *} \\
(-2.00)\end{array}$ & $\begin{array}{l}-6.481 \\
(-0.74)\end{array}$ & $\begin{array}{l}54.58 \\
(1.58)\end{array}$ \\
\hline Observations & 411 & 425 & 425 & 400 & 419 \\
\hline F-test & $24.95 * * *$ & $50.21 * * *$ & $20.90 * * *$ & $2.64 * * *$ & 14.40 \\
\hline Sargan test & 7.11 & 2.8 & 1.31 & 0.81 & 0.60 \\
\hline $\operatorname{AR}(1)$ & $-5.29 * * *$ & $-1.60 *$ & $-6.82 * * *$ & -0.63 & $-2.22 * *$ \\
\hline $\operatorname{AR}(2)$ & -0.32 & -0.72 & $-1.05^{*}$ & -0.35 & -1.13 \\
\hline
\end{tabular}

Table reports dynamic specification of BHC risk-taking determinants. The models are estimated using GMM System and include year dummies. F-test is a test of the joint significance of reported coefficient estimates under null hypothesis. Sargan test is a test of overidentifying restrictions under the null of instrument validity. $\mathrm{AR}(1)$ and $\mathrm{AR}(2)$ are tests for first and second order serial correlation in residuals. $t$ statistics in parentheses. ${ }^{*} p<0.10,{ }^{* *} p<0.05,{ }^{* * *} p<0.01$

are assumed to be contemporaneously correlated. The results are reported in Table 5 . The results are consistent with the results based on 2SLS. Duality has positive and significant impact on bank risk measures, except $\mathrm{Z}$ score. This suggests that Duality is a key 
determinant for key bank risk indicators, namely Non-Performing Loans, Tier 1, Tail Risk, and Efficiency Ratio.

As mentioned earlier, a second possible cause of endogeneity is omitted variables bias (Lee et al. 2016a, b). As such, results are presented based on panel data analysis, where bank fixed effects are controlled for in the estimations. In particular, the baseline regression is augmented by including the lagged dependent variable of risk measures, leading to dynamic panel data setting specification. ${ }^{6}$ In this specification, the lagged risk dependent variable is allowed to be correlated with unobserved heterogeneity. This suggests the use of an instrumental variables methodology to estimate the augmented baseline regression, where the lagged dependent bank risk measures and Duality are instrumented. The preferred estimator for this specification is the Generalised Method of Moments (GMM) system estimator (Arellano and Bover 1995; Blundell and Bond 1998). This is an instrumental-variables procedure that not only controls for firm fixed effects but also provides consistent and efficient coefficient estimates in the presence of a lagged dependent variable. $^{7}$

Table 6 presents the results of this dynamic panel data analysis for further robustness checks following Wang (2011). The Sargan test of over-identifying restrictions is not significant, indicating that the instruments used in the estimation are less likely to be correlated with the error term (i.e. valid instruments). The $\operatorname{AR}(1)$ and $\operatorname{AR}(2)$ tests confirm the existence of serial correlation of order one, but not of order two for NPLs, Tier 1, Tail Risk, and the Efficiency Ratio. The results suggest that the dynamic nature of bank risk measures is not rejected for the models based on Non-Performing Loans, Tail Risk, and the Efficiency Ratio. But for the models based on Tier 1 and $\mathrm{Z}$ score there is no evidence for dynamic setting. With regard to the effect of Duality on bank risk measures, the dynamic setting estimation shows that Duality has a positive effect on NPLs, Z score and the Efficiency Ratio, and the effect is significant at the 5\% level. While for Tier 1 model, it is only significant at the $10 \%$ level. Overall, the dynamic setting specification results confirm the baseline regression findings.

\subsection{Alternative measure of CEO power}

So far, Duality is used as a proxy for CEO power. The authors acknowledge that other CEO-related characteristics other than Duality could contribute to CEO power. For example, the CEO may exhibit educational, board power industry networking skills or remuneration-based characteristics that may drive BHC outcomes (Custodio and Metzger 2014; King et al. 2016). This section of this paper describes how an index has been created to proxy CEO power as an alternative determinant of BHC risk-taking. Principal Component Analysis (PCA) is a multivariate technique that extracts information from data to display patterns of similarity and has been applied in bank risk governance research (Ellul and Yerramilli 2013). The advantage of PCA is that it facilitates the construction of a CEO power proxy without assigning arbitrary weightings for each individual variable (Tetlock 2007).

\footnotetext{
6 The dynamic setting allows one to account for the fact that the measure for risk-taking may be serially correlated.

7 Dynamic specifications have been employed in similar contexts of risk-taking including Delis and Kouretas (2011) and Fiordelisi et al. (2011) for nonperforming loans, whereas Ellul and Yerramilli (2013) apply it for bank tail risk, and Bharati and Jia (2018) resort to this approach for Total Risk.
} 
Four new variables relating to the CEO Power index are collected and reported in “Appendix 3", namely CEO Recruited Inside, CEO Busyness, CEO Education and CEO Total Annual Compensation mix, for the new CEO Power Index. This analysis continues with the CEO Power Index variable added to the baseline model (which includes Duality) as a robustness check. These estimations (reported in Table 7) validate Duality as a powerful determinant of risk-taking as before relative to the new variable proxied by CEO Power. ${ }^{8}$ Duality remains one or five per cent significant and positively related to NPLs, Tier 1, Tail Risk and the Efficiency Ratio, as before. In no scenario reported is the CEO Power index significantly related to BHC outcome measures. ${ }^{9}$ The evidence continues to support the initial findings that Duality as a governance structure is robustly associated with BHC risk-taking. ${ }^{10,11}$

\subsection{What is the impact of enhanced monitoring on BHC risk-taking?}

As noted above, the Dodd-Frank Act (2010) designated certain banks as SIFIs. ${ }^{12}$ Akhigbe et al. (2015) show that US financial institutions experience a reduction in discretionary risk-taking after the adoption of this act. Using data from Barth and Sau (2015) to identify US BHCs which are SIFIs, this study now delimits SIFIs from non-SIFIs and estimates a horserace regression between the two subgroups of BHCs. SIFIs are different from nonSIFIs in that they are subject to greater supervisory scrutiny and board-level arrangements, such as stress tests and the adoption of a Risk Committee, Risk Appetite and CRO related requirements (Federal Register 2014a and b, Barth 2015; Gontarek and Belghitar 2018).

Table 8 reports the results of this analysis, reporting ten columns of output, five models for those BHCs designated as SIFIs and five models for those BHCs designated as non-SIFIs. Now the study results begin to diverge. Only now does Duality exhibit an nonsignificant statistical relationship to risk-taking in Models 1-5 (which are BHCs subject to greater monitoring intensity). This indicates that the relationship between Duality and risk-taking measures dissipates where BHCs are subject to greater supervision. However, for the non-SIFI BHCs reported in Models 6-10 of Table 8, Duality continues to report the same positive (and at times significant) relation with NPLs, Tier 1, and Tail Risk (but not the Z-score and the Efficiency Ratio). This analysis provides some evidence that the enhanced monitoring associated with SIFIs (versus non-SIFIs) may be an effective substitute for mitigating agency costs stemming from Duality.

\footnotetext{
${ }^{8}$ CEO Total Annual Compensation Mix is also added to the baseline model with the results unchanged as before with respect to the relation of Duality and the suite of Dependent Variables, whereas CEO Total Annual Compensation Mix itself is not significant at the five or one per cent level in this further unreported finding.

9 All explanatory variables are lagged in this battery of tests as in Table 3 Models 6-10.

${ }^{10}$ In further robustness testing, the CEO Power index was again used in the baseline estimations, this time while removing Duality from the model. So, CEO Power now replaces Duality as the independent variable of interest in these estimations. In this round of analysis, CEO power does not provide an effective prediction of BHC risk-taking and validating the primacy of the role of Duality over CEO Power.

11 In order to further validate the primacy of Duality over other measures of CEO Power noted within the literature, a further test was conducted. First, each of the aforementioned variables used to construct the CEO Power index were added as control variables to the baseline regressions. In this battery of tests, Duality continued to demonstrate qualitatively similar results in its relation to BHC risk-taking measures.

12 SIFIs or Systemically Important Financial Institutions are designated with a * in "Appendix 2".
} 
Table 7 CEO Power and its impact upon BHC Risk-Taking Determinants (Adding further CEO related explanatory variables)

\begin{tabular}{|c|c|c|c|c|c|}
\hline & $1 \mathrm{NPLs}$ & 2 Tier 1 & 3 Tail Risk & $4 \mathrm{Z}$-score & 5 Efficiency ratio \\
\hline Duality & $\begin{array}{l}0.181 * * * \\
(2.71)\end{array}$ & $\begin{array}{l}0.861 * * * \\
(3.08)\end{array}$ & $\begin{array}{l}9.168 \text { *** } \\
(2.66)\end{array}$ & $\begin{array}{l}-0.0108 \\
(-0.13)\end{array}$ & $\begin{array}{l}5.875^{* *} \\
(2.02)\end{array}$ \\
\hline CEO power index & $\begin{array}{l}0.0317 \\
(1.15)\end{array}$ & $\begin{array}{l}-0.124 \\
(-1.02)\end{array}$ & $\begin{array}{l}-1.443 \\
(-0.90)\end{array}$ & $\begin{array}{l}-0.0103 \\
(-0.29)\end{array}$ & $\begin{array}{l}-0.0438 \\
(-0.04)\end{array}$ \\
\hline $\mathrm{CEO}$ & $0.102 * *$ & 0.195 & $10.71 * *$ & $-0.168 * * *$ & -0.0146 \\
\hline Tenure & $(2.43)$ & $(1.31)$ & $(2.49)$ & $(-3.22)$ & $(-0.01)$ \\
\hline CEO & $-0.135^{* * *} *$ & 0.186 & $-8.519 * * *$ & 0.0176 & -0.953 \\
\hline Shareholding & $(-4.89)$ & $(1.50)$ & $(-5.23)$ & $(0.57)$ & $(-1.11)$ \\
\hline TARP & $\begin{array}{l}-0.0157^{*} \\
(-1.66)\end{array}$ & $\begin{array}{l}-0.195 * * * \\
(-3.85)\end{array}$ & $\begin{array}{l}-0.500 \\
(-1.17)\end{array}$ & $\begin{array}{l}0.0164 \\
(1.49)\end{array}$ & $\begin{array}{l}0.737 * * * \\
(3.14)\end{array}$ \\
\hline Board size & $\begin{array}{l}-0.0596 \\
(-1.22)\end{array}$ & $\begin{array}{l}-0.779 * * * \\
(-3.96)\end{array}$ & $\begin{array}{l}-11.09 * * \\
(-2.53)\end{array}$ & $\begin{array}{l}0.185^{* * *} \\
(3.35)\end{array}$ & $\begin{array}{l}-1.544 \\
(-1.38)\end{array}$ \\
\hline $\mathrm{BHC}$ size & $\begin{array}{l}-0.00262 \\
(-0.77)\end{array}$ & $\begin{array}{l}-0.0129 \\
(-1.05)\end{array}$ & $\begin{array}{l}0.325^{*} \\
(1.83)\end{array}$ & $\begin{array}{l}0.00238 \\
(0.77)\end{array}$ & $\begin{array}{l}0.00272 \\
(0.04)\end{array}$ \\
\hline Deposits & $\begin{array}{l}-0.000886 \\
(-0.38)\end{array}$ & $\begin{array}{l}-0.0567 * * * \\
(-6.42)\end{array}$ & $\begin{array}{l}0.308 * * \\
(2.33)\end{array}$ & $\begin{array}{l}-0.00299 \\
(-1.60)\end{array}$ & $\begin{array}{l}-0.162 * * * \\
(-3.24)\end{array}$ \\
\hline Total loans & $\begin{array}{l}0.0602 \\
(1.52)\end{array}$ & $\begin{array}{l}-0.378^{* *} \\
(-1.99)\end{array}$ & $\begin{array}{l}-3.961 * * \\
(-2.10)\end{array}$ & $\begin{array}{l}0.158 * * \\
(2.53)\end{array}$ & $\begin{array}{l}-1.596 \\
(-1.28)\end{array}$ \\
\hline Year dummies & Yes & Yes & Yes & Yes & Yes \\
\hline Observations & 251 & 260 & 261 & 252 & 260 \\
\hline Adjusted $R^{2}$ & 0.2132 & 0.3912 & 0.3543 & 0.2171 & 0.0699 \\
\hline
\end{tabular}

Notes Table 7 reports BHC risk-taking determinants for the baseline model but includes a new explanatory variable for CEO Power as an alternative explanation to drive risk-taking. CEO Power is a new variable created with PCA by combining four CEO focused variables of interest for each year of the sample, CEO Recruited Inside (a dummy variable if the CEO was (or was not) recruited from within the BHC, CEO Busyness (measuring total number of board roles held by the CEO), CEO Education (a dummy variable if the BHC CEO holds an advanced business, law, economics degree or other CPA type designation), and Total CEO Annual Compensation Mix (the total annual USD compensation included across all awards, measured as a $\log$ value). The idea is to attempt to capture the impact of other CEO related results upon BHC outcome measures. All $t$ statistics in parentheses. Heteroskedasticity is corrected using robust standard errors. Estimations include year-dummies, unreported. Significance levels: $* p<0.10$, ** $p<0.05$, *** $p<0.01$. "Appendix 3" reports the formation of the CEO Power Index

\subsection{Inclusion of enhanced governance practices and mitigation of omitted variables}

In the next set of estimations, further governance mechanisms added to the previous SIFI related model to further mitigate omitted variable bias (Black and Kim 2012). This new governance data is reported in Table 1. Beginning with governance variables, board independence in considered. Vallascas et al. (2017) show that an increase in board independence leads to more prudent risk-taking. External directors without strong inside connections can moderate agency conflicts (de Andres and Vallelado 2008; Switzer and Wang 2013). The percentage of Non-Inside Directors on the board is thus used in the next estimations. 
Risk management is central to the business of banking (Stulz 2015; Custódio and Metzger 2018). Regulators published guidelines for improved risk governance, including the importance of the risk committee, the use of risk appetite frameworks and experienced and independent CROs (FSB 2013, OCC 2014, Federal Register Federal Register. 2014a, $\mathrm{b}$ and Basel 2015). The impact of monitoring is incorporated by adding these governance variables. The existence of a board-level Risk Committee provides a nexus of risk-based communication (Hines and Peters 2015; Holmquist 2014). Risk Committee is measured as one (or zero) dummy upon the existence of this forum (Hines and Peters 2015). Establishing firm-wide risk appetite levels is an important role of the Risk Committee (Sabato 2009; Gontarek and Bender 2018). Bank Director reports that $94 \%$ of US banks with assets greater than $\$ 10$ billion validate that establishing risk appetite is a key aim of the risk committee. The adoption of board level Risk Appetite frameworks is collected from Risk Committee charters, generating a one (or zero) dummy variable. Gontarek and Belghitar (2018) find a robust relationship for risk governance mechanisms and lower risk-taking.

The final two risk governance variables relate to the strength of the Chief Risk Office (CRO) to pursue a risk oversight agenda. The Federal Register (2014a and b) define the need for covered US BHCs to name a CRO to provide independent monitoring of risk profiles. ${ }^{13}$ Two new CRO-related variables are thus introduced. CRO Centrality is measured as the ratio of the CRO's total compensation to the CEO's total compensation in order to measure the relative power of the CRO (Ellul and Yerramilli 2013). The final risk governance variable is CRO Tenure, measured as the number of years the CRO worked for the BHC. The Federal Register (2014b, p. 17289) indicates that the CRO shall have experience in identifying, assessing, and managing risk exposures of large complex firms and tenure is one means to proxy this standard.

Once more, the same SIFI and non-SIFI sub-samples are examined to ascertain the role that varying intensity levels of monitoring may play in curtailing the agency costs associated with Duality. While the SIFI and non-SIFI sub-samples each exhibit Duality, they surprisingly exhibit different levels of risk governance adoption.

"Appendix 4" presents a difference-in-means analysis for risk governance mechanisms for more and less intensely monitored BHCs. SIFI (non-SIFI) mean values reported for Board non-insiders are $41 \%$ (24\%), CRO Centrality 28\% (24\%), CRO Tenure 12.4-years (7.7-years), Risk Appetite 54\% (19\%) and Risk Committee 88\% (64\%). This differencesin-means analysis provides some indication of a greater rate of adoption of risk governance oversight for SIFI BHCs relative to non-SIFIs. Interestingly, SIFIs report Duality at $80 \%$ (versus $44 \%$ for non-SIFIs), so enhanced risk governance practices comfortably co-exist with this governance structure.

The baseline regressions are now re-estimated with the above new governance-related controls in Table 9, following the same model set-up used above. ${ }^{14}$ Models $1-5$ report the findings for Duality in more regulated BHCs in Table 9. Duality for all models in this suite of regressions is statistically non-significant to risk-taking, save Tier 1 . The results for Tier 1 may be driven by greater regulatory capital requirements demanded by regulators.

\footnotetext{
13 A covered BHC for the purpose of heightened risk governance is a BHC with assets of $\$ 50$ billion or more (Federal Register 2014a and b).

14 If these variables are added instead to the full sample and re-estimated, Duality once again is robustly related to BHC risk-taking, with a 5\% relation to NPLs, Tier 1, and the Z-score and one per cent related to Tail Risk in un-reported results to conserve space. Duality records a ten per cent relation to lower levels of BHC efficiency in this case as well.
} 


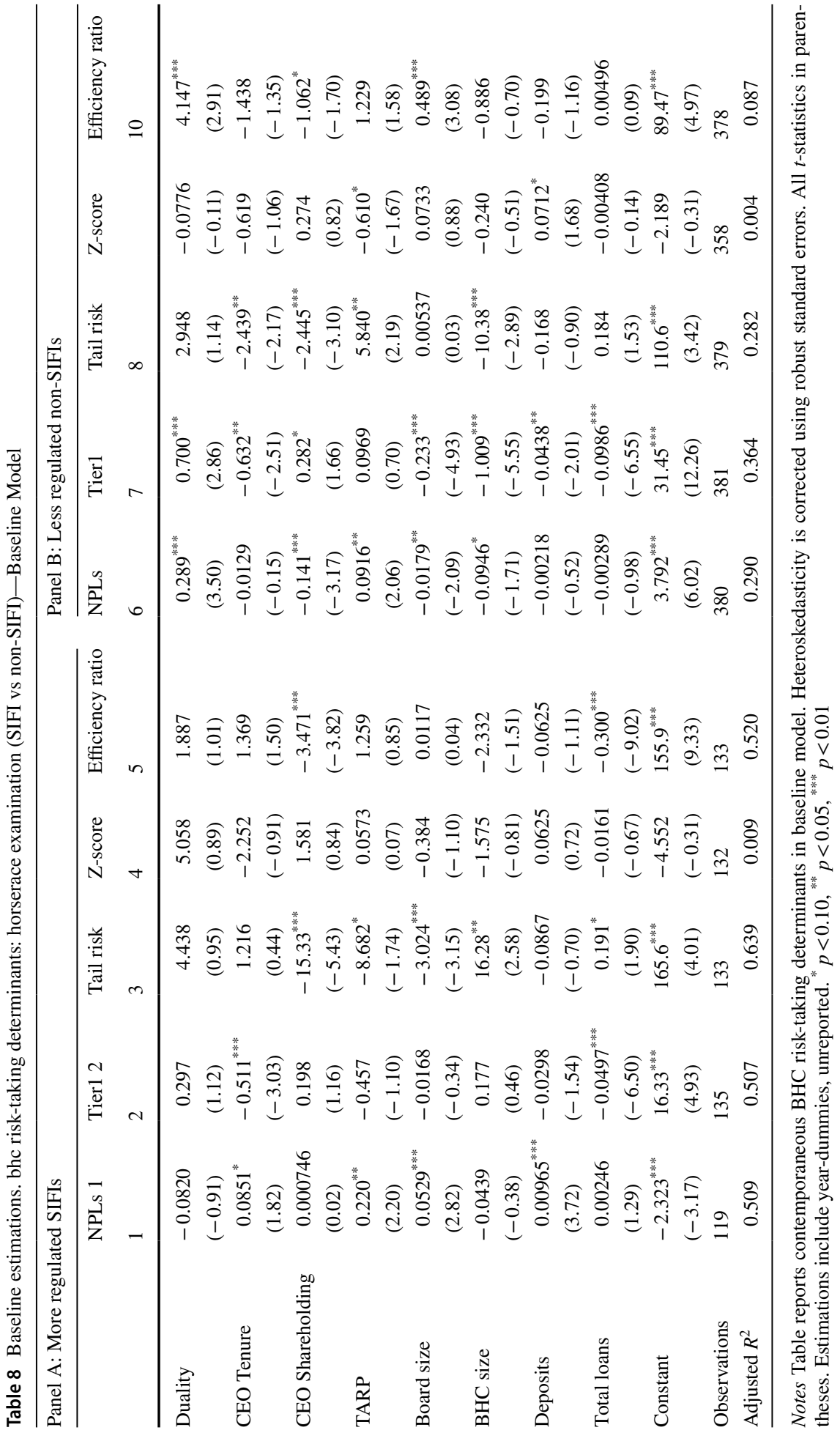


Table 9 also reports the same analysis for non-SIFIs across Models 6-10. As before, the coefficients for Duality remain positive and significant in Panel B for NPLs, Tier 1, Tail Risk and the Efficiency Ratio. A further interesting observation in Panel B is that lesser levels of certain risk governance mechanisms (i.e., Risk Appetite and CRO Centrality, for example) are significant and significantly related to risk-taking measures, as evidenced by their negative co-efficient values.

Table 9 presents further evidence of the substitution effect of internal monitoring in curtailing excessive risk-taking, even when Duality is observed in Panel A. BHCs that are subject to greater levels of monitoring intensity no longer exhibit a significant relationship with NPLs, Tail-Risk and Efficiency measures. These results are consistent with Vallascas et al. (2017) who analyse growing board independence levels for an international sample of banks and note that banks under heavier regulation opt for greater risk-oversight and report lower risk-taking measures. It is noteworthy in Table 9 that BHCs that are subject to relatively lower levels of monitoring intensity continue to report a similar positive robust relation between Duality and risk-taking, as before. This is a significant finding which resonates with governance substitution theory noted in the literature (Krause et al. 2014; Wang et al. 2019; Rediker and Seth 1995), indicating that robust board governance structures can provide effective oversight even if Duality is employed as a governance structure.

\section{Conclusion and discussion}

A controversial issue commonly debated is whether or not a bank CEO should also hold the title of Chairman (Larcker and Tayan 2016). US BHCs are an important industry sector to assess this issue given its systemic risk considerations and the practice of this governance structure, unlike certain other jurisdictions around the world. Theory argues that the separation of the CEO and Chairman roles results in limited monitoring (Grove et al. 2011). An independent board Chairman constructively challenges the CEO (Tonello 2011) and strengthens governance checks and balances (Basel 2015). Consistent with Vallascas et al. (2017), Li and Roberts (2018) and Elamer et al. (2018), this study presents evidence that boardroom structure matters to risk-taking in financial institutions.

This research reports a robust positive relation between Duality and risk-taking across a battery of tests. It also examines this governance structure to find a consistent relation with lower efficiency; that it, BHCs managed by CEO Chairman appear on average, to be less efficient, thus potentially generating a feedback loop with adverse risk-taking incentives (Fiordelisi et al. 2011). Notwithstanding its predictive power for NPLs, Tier 1 capital, Tail Risk and efficiency, Duality is not a predictor for the Z-score, possibly as this measure does not observe weakening earnings or capital trends following the significant TARP and support programs instituted by authorities (Chiaramonte et al. 2016).

Is Duality bad for effective corporate governance of banks? The answer may be it depends in part on the strength of interactions of other monitoring mechanisms in place.

Across this study, Duality is associated with a greater risk-taking as noted in baseline and lagged estimations, 2SLS, 3SLS, dynamic panel data and other empirical settings. Consistent with Chen and Lin (2016), Tang (2016) and Lu and Boateng (2018), when Duality exists, an important balancing tool to curb agency conflicts is removed and board independence may be jeopardized which can lead to greater risk-taking incentives. As noted by de Haan and Vlahu (2015) and Hardwick et al. (2011), one possible explanation 


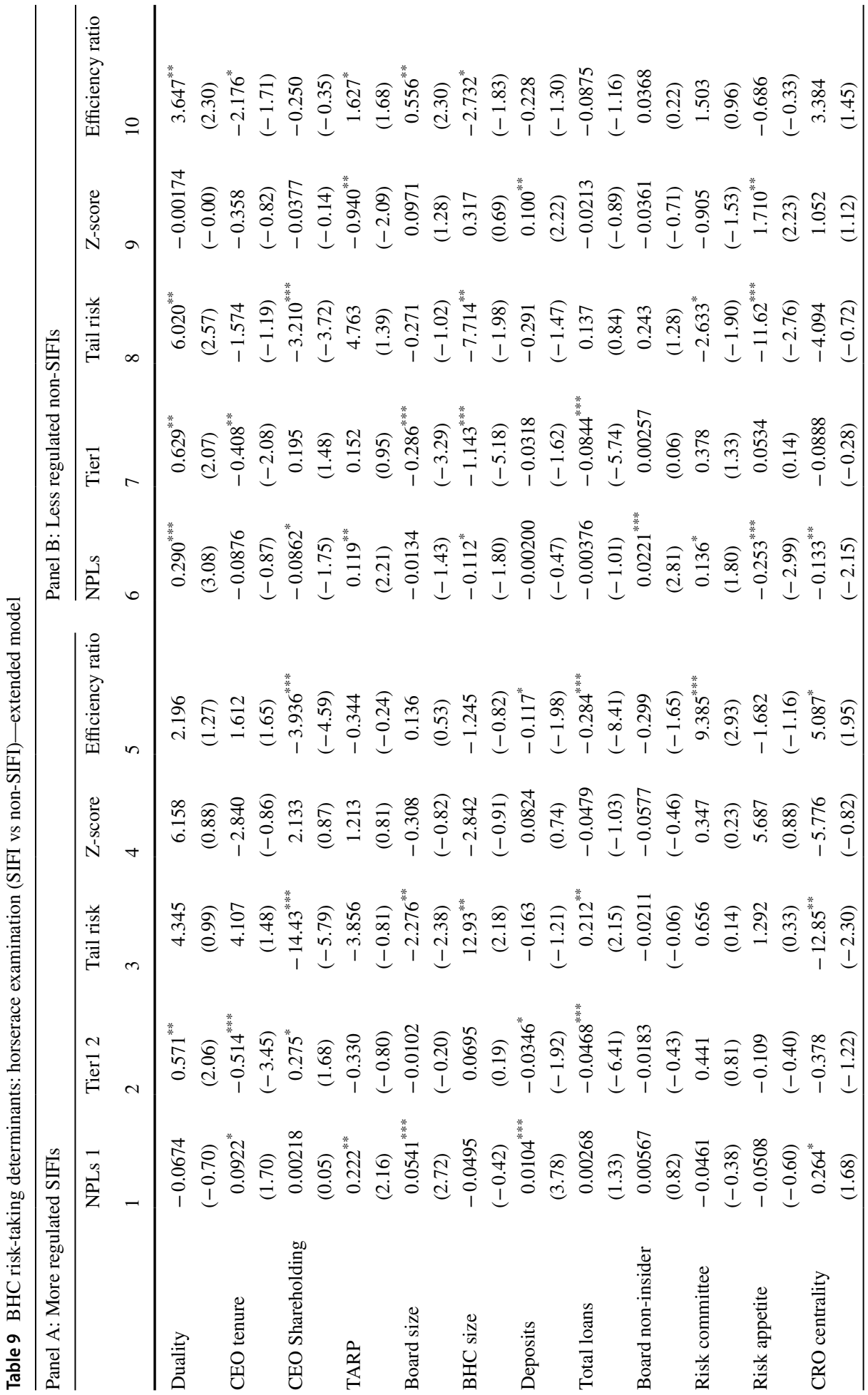




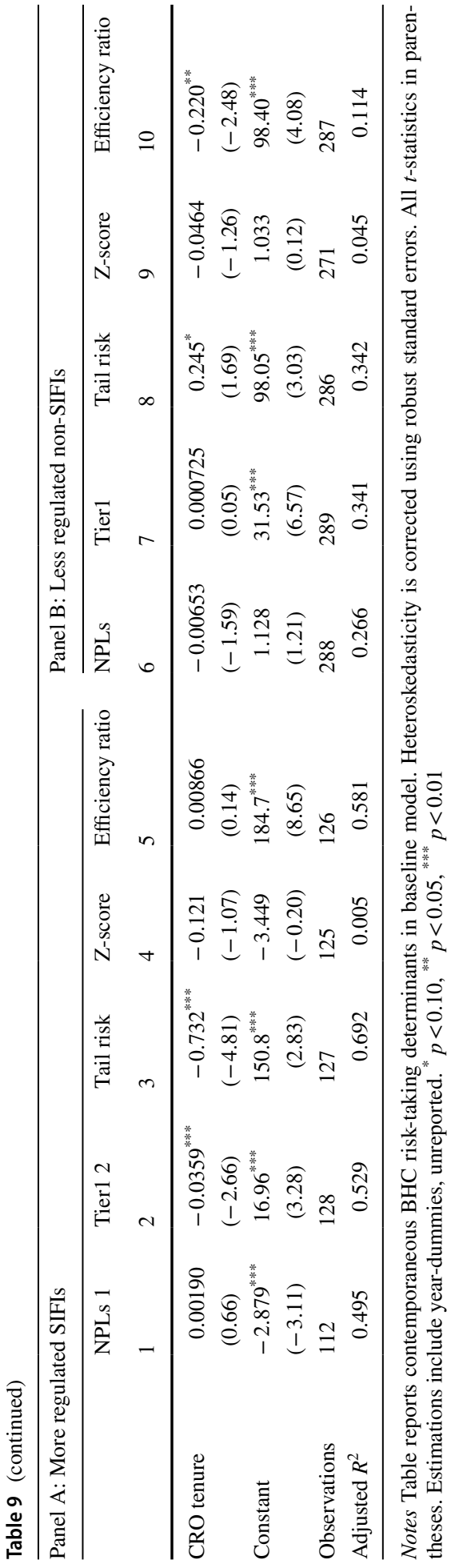


for these findings is that Duality may impact boardroom communication and disrupt freeflow of information, impacting effective risk oversight.

This research extends its findings to also present evidence that a balance for effective risk-taking appears to be restored by the imposition of other monitoring activities. Specifically, this study next delimits BHCs that are subject to lighter regulation intensity from those BHCs which are subject to greater monitoring intensity. In this round of examinations, the earlier positive relation between Duality and risk-taking continues as before for BHCs with lower monitoring standards. However, the robust association between the CEO Chairman role and risk-taking measures completely dissipates for BHCs that embrace heightened monitoring. These results are consistent with Akhigbe et al. (2015) who examine larger financial institutions (which are often subject to greater regulation) and experience lower degrees of discretionary risk-taking. This evidence indicates that agency costs related to Duality may be offset by other effective internal and external monitoring mechanisms, which correct imbalances which may otherwise occur (Misangyi and Acharya 2014).

The contrasting view presented by Pi and Timme (1993, page 529) indicates "for those banks where the CEO is also Chairman of the board, internal monitoring devices may not be as effective as envisioned in the literature. Consequently, Chairman-CEOs may be less inhibited from engaging in non-value maximizing behaviour".

However, the evidence presented in this research setting suggests otherwise. Regulators require firms to adopt effective corporate governance structures in order to promote safety and soundness. Non-value maximizing and excessive risk-taking behaviours may be curbed by regulatory initiatives as well as enhanced internal monitoring. As noted by $\mathrm{Lu}$ and Boateng (2018), the board's monitoring responsibility is to scrutinize managerial actions to reduce harmful behaviours, including excessive risk-taking. The evidence presented in this paper indicates that BHCs managed by a CEO Chairman that embrace other forms of intense monitoring can realise the best of unity of command (originating from Duality) without unwanted agency costs that might otherwise plague such governance structures. This is a contribution to the debate on corporate governance of banks.

Several limitations exist with respect to these findings. As much of this analysis relies on a cross-sectional design, caution should be taken before inferring any causal relations between the variables, notwithstanding the series of robustness tests undertaken herein. Being US focused, the findings may not be generalizable in other jurisdictional contexts; further international samples could be collected to examine this issue. In terms of further research, examining the impact of Duality and a broader set of BHC performance (rather than risk variables) and a related channels analysis would contribute to the literature domain for bank corporate governance. Also, examining the risk cultures of banks that are driven by governance structures such as Duality would be highly useful to practitioners who are now focused on conduct risks (Sheedy and Griffin 2017). Lastly, considering the role of the lead or senior independent director as a means to mitigate agency cost incentives would be interesting given a number of BHCs that have adopted this role including JP Morgan Chase and Co and Goldman Sachs Inc. (Krause et al. 2014).

For fellow researchers, this study contributes to literature regarding the effects of corporate governance mechanisms and their substitutability to control excessive risk-taking. It provides evidence of the determinants of risk-taking and contributes to an emerging literature domain that argues that overall robust governance arrangements can overcome agency costs associated with a dummy variable defining Duality (Wang et al. 2019; Krause et al. 2014). These findings are consistent with Hardwick et al. (2011) who argue that corporate governance is best evaluated in its entirety given possible interactions between different 
monitoring features. While the combined CEO Chairman role is believed to restrict riskbased information flows and result in greater agency costs (de Haan and Vlahu 2015), the application of effective risk governance arrangements can realign risk-taking to more tolerable levels.

For practitioners including bank CEOs, board members and bank regulators, this research adds timely new evidence with respect to the on-going debate about optimal board structure and monitoring trade-offs. Regulators encourage firms to adapt their corporate governance arrangements to mitigate agency costs (Schäuble 2019). Practically, to the extent that governance mechanisms are costly, they can be partially substituted for one another ((Duru etal. 2016; Enache and Hussainey 2019). This study also raises questions as to the appropriateness of relaxing US bank asset thresholds just as regulators are now refining their supervisory approach (Congressional Research Service 2017; FDIC 2018, NYT 2019).

From a policy perspective, these results suggest that no single variable such as Duality can capture an issue as complex as financial institutions governance profiles (Byrd et al. 2012). Instead, the overall bundle of governance arrangements and external supervision or monitoring appears to be far more relevant to fully appreciate the trade-off of monitoring choices available to board directors (Rediker and Seth 1995). As noted by Misangyi and Acharya (2014; page 1702), no single monitoring mechanism can serve as a "silver bullet" in matters of corporate governance.

Acknowledgements The authors would like to thank Professor Cheng-Few Lee (Editor), the Journal Reviewer for their constructive review comments, Professor Ed Altman, Dr Gabriele Sabato, Dr Andrea Moro, Dr Nemaja Radic, Dr Alessandra Tanda, Phil Sullivan and the participants of the International Corporate Governance Society (ICGS) 5th Annual Conference held at Essex Business School, Colchester, UK, 2019.

Open Access This article is licensed under a Creative Commons Attribution 4.0 International License, which permits use, sharing, adaptation, distribution and reproduction in any medium or format, as long as you give appropriate credit to the original author(s) and the source, provide a link to the Creative Commons licence, and indicate if changes were made. The images or other third party material in this article are included in the article's Creative Commons licence, unless indicated otherwise in a credit line to the material. If material is not included in the article's Creative Commons licence and your intended use is not permitted by statutory regulation or exceeds the permitted use, you will need to obtain permission directly from the copyright holder. To view a copy of this licence, visit http://creativecommons.org/licenses/by/4.0/.

\section{Appendix 1: empirical definition of the variables}

\begin{tabular}{ll}
\hline Dependent variables & Definition and source \\
\hline Efficiency ratio & Measured as non-interest expense divided by revenues, following Lu and Boateng \\
& (2018), Akhigbe and Stevenson (2010) and Jacewitz and Kupiec (2012). This \\
& data is collected via Bloomberg. The Efficiency Ratio is a practical measure used \\
& in everyday banking, indicating the fraction of one dollar required to produce one \\
& dollar of revenue excluding funding costs, so lower values indicate more efficient \\
& banks. \\
& Non-performing loans (NPLs) is the annual USD amount of non-performing \\
& loans scaled by Total Loans in USD, following Ellul and Yerramilli (2013) and \\
& Zagorchev and Gao (2015). NPLs are an overall indicator of BHC quality and \\
& credit portfolio quality (OCC Director's Handbook 2016; Keffala 2017). Data \\
NPLs \% & collected via Bloomberg. \\
\hline
\end{tabular}




\begin{tabular}{|c|c|}
\hline Dependent variables & Definition and source \\
\hline Tail risk & $\begin{array}{l}\text { Tail Risk is defined as the negative of the average return on the firm's stock over } \\
\text { the five per cent worst days in a given year, following Ellul and Yerramilli (2013), } \\
\text { Kashyap et al. 2008). The need to mitigate tail risk rises from excessive risk- } \\
\text { taking which is unresponsive to supervision and market discipline (Ellul 2015). } \\
\text { Tail Risks can be the outcome of a failure of effective risk management systems } \\
\text { at banks (SSG 2008, 2009). }\end{array}$ \\
\hline
\end{tabular}

Tier 1 capital Tier 1 capital is the ratio of Tier 1 capital to a BHC's risk weighted assets. It is a measure of regulatory capital held against risk and is collected from Bloomberg, following Minton et al. (2014), and Beltratti and Stulz (2012).

Z-score log And CAR Following Laeven and Levine (2009), Radic et al. (2012) and Vallascas et al. (2017), the Z-score for banks is defined as the sum of the mean value of the annual ROA plus the mean value of the Capital Asset Ratio or "CAR", divided by the standard deviation of annual ROA over the preceding three years. Following Belghitar and Clark (2012), a Z-score is computed as $\mathrm{Z}=\{[$ Average $($ ROA $)+$ Average (Capital Asset Ratio/Total assets) $] / \sigma$ (ROA) $\}$. ROA and Capital Asset Ratio is averaged over the preceding three year period. Within the Z-score formula, the Capital Asset Ratio is defined as: Total Assets minus Total Liabilities, divided by Total Assets, following Bhagat et al. (2015), Laeven and Levine (2009) and Bai and Elyasiani (2013). Calculated this way, the Z-score has an inverse form, i.e. $1 / Z$, in order to make the interpretation of the signs of coefficients comparable. Thus, a high Z-score means more default risk. Log values used in all estimations.

Other variables

BHC Size (log)

USD value (log) of BHC assets from the US Federal Reserve Bank website for each year-end reporting period. The log value is used in all estimations following Chen et al. (2018).

BODNon-insider \% Percentage of non-executive directors, as published by BoardEx, denoting directors who are not currently affiliated with management.

Board size

Number of persons on the board of directors, collected via BoardEx.

CEO age (Log)

Measures the age of the BHC CEO (log) following Cornett et al. (2009), Palia (2001) and Brick et al. (2006). This variable is used as an instrument in 2SLS regression following Yang and Zhou (2014). Skala and Weill (2015) and Ho et al. (2016) also employ CEO age to examine the determinants of NPLs, Tier 1 and the Z-score as also employed in this study. Collected via Bloomberg.

CEO tenure

Measures the tenure in years that a $\mathrm{CEO}$ has sat on the $\mathrm{BHC}$ board of directors, either as a CEO or in any other role (such as an independent board member). These variable proxies the CEOs comfort and influence at the board. Li and Roberts (2018) evaluate CEO board membership and firm outcomes to find it a predictor for greater performance, notably in complex firms. Landier, Sauvagnat, Sraer and Thesmar (2013) measure a director's independence if they have been appointed before the current CEO. This data is collected via BoardEx.

Duality

A dummy variable with a value of one (or zero) if the CEO also is Chairman, following Hagendorff and Vallascas (2011); Yang and Zhao (2014) and Tang (2016).

CEO ownership The total USD holding of BHC shares held by the CEO each year, whether awarded as part of a long-term incentive scheme or purchased voluntarily, following Aebi et al. (2012); Chung and Pruitt (1995) and Onali et al. (2016). CEO Ownership is collected from Bloomberg. The log value is used in all estimations. 
Dependent variables Definition and source

CEO power index $\quad$ CEO Power is an index created by applying Principal Component Analysis (PCA) to four underlying CEO power variables and noted: CEO Recruited Inside is a dummy variable assigned 1 (otherwise 0 ) if the CEO directly preceding role was within the BHC (or not), following Pathan (2009). CEO Busyness is a variable the measures the number of total board memberships (including the BHC) held by the CEO, following Cooper and Uzun (2012). CEO Busyness can portray "endorsement benefits" as noted by Nguyen et al. (2015). CEO Education is dummy variable assigned a value of 1 (otherwise 0 ) if the CEO's educational credentials meets those defined by Güner et al. (2008). CEO Total Annual Compensation Mix (Larcker and Tayan 2017) is the total USD compensation reported for the CEO from salary, stock and other benefits as reported by Morningstar. All data collected via BoardEx unless otherwise noted.

CRO centrality CRO Centrality is defined as the ratio of the CRO's total compensation, excluding stock and options, to the CEO's total compensation, following Ellul and Yerramilli (2013); Keys et al. (2009) and Bushman et al. (2018). CRO and CEO total compensation is collected using Morningstar.

CRO tenure $\quad$ Measures the number of years a $\mathrm{CRO}$ has worked in that role at the BHC following Amoozegar et al. (2017). Tenure is used in governance studies for directors, CEOs and other executives to proxy experience (Tanda 2015; Booth et al. 2002 and Swizter and Sahut 2015).

Deposits \%

Measured as total deposits divided by total assets as collected from Bloomberg.

Risk appetite \% Existence of risk appetite arrangements at the BHC board levels is hand-collected from BHC risk committee charters collected on-line, following Gontarek and Belghitar (2018). This variable assigns a dummy one (zero) if the board must explicitly approve BHC risk appetite.

Risk committee \% This dummy is defined as the existence of a BHC board-level risk committee, as reported in BoardEx.

TARP

This measures the amount of BHC TARP funding, following Carty and Weiss (2012) and Nwaeze et al. (2018). TARP amounts were collected via https://proje cts.propublica.org/bailout/ following Shah et al. (2017).

Total loans \%

Total loans are the total loans divided by total assets collected via Bloomberg, following Switzer and Wang (2013); Kupeic and Lee (2012) and Battaglia and Gallo (2015).

\section{Appendix 2: list of BHCs}

\begin{tabular}{llllll}
\hline$\#$ & BHC Name & $\#$ & BHC Name & $\#$ & BHC Name \\
\hline 1 & JP MORGAN CHASE \& & 47 & $\begin{array}{l}\text { TEXAS CAPITAL BANC- } \\
\text { CO * }\end{array}$ & 94 & FIRST FNCL BSHRS \\
& BANK OF AMERICA & 48 & PACWEST BANCORP & 95 & First Bank \\
& CORP * & & & \\
3 & WELLS FARGO \& CO * & 49 & UMB FINANCIAL CORP & 96 & RENASANT CORP \\
4 & CITIGROUP INC * & 50 & PRIVATEBANCORP INC & 97 & FIRST MERCHANTS CORP \\
5 & US BANCORP INC * & 51 & IBERIA BANCORP & 98 & TOWNEBANK \\
6 & PNC FINANCIAL SER- & 52 & F N B CORP & 99 & OPUS BK \\
& VICES INC * & & & & \\
7 & BANK OF NEW YORK & 53 & BANK OF HAWAII CORP & 100 & EAGLE BANCORP, INC \\
& MELLON * & & & \\
\hline
\end{tabular}




\begin{tabular}{|c|c|c|c|c|c|}
\hline$\#$ & BHC Name & \# & BHC Name & $\#$ & BHC Name \\
\hline 8 & STATE STREET CORP * & 54 & $\begin{array}{l}\text { ASTORIA FINANCIAL } \\
\text { CORP }\end{array}$ & 101 & TALMER BANCORP INC. \\
\hline 9 & $\begin{array}{l}\text { CAPITAL ONE FINAN- } \\
\text { CIAL CORP * }\end{array}$ & 55 & WASHINGTON FED INC & 102 & $\begin{array}{l}\text { UNITED BANKSHARES } \\
\text { INC/WV }\end{array}$ \\
\hline 10 & SUNTRUST BANKS INC * & 56 & MB FINANCIAL INC/MD & 103 & STIFEL FNCL CORP \\
\hline 11 & $\mathrm{BB} \& \mathrm{~T} \mathrm{CORP} *$ & 57 & RAYMOND JAMES FNCL & 104 & FLUSHING FC \\
\hline 12 & $\begin{array}{l}\text { AMERICAN EXPRESS } \\
\text { CORP } *\end{array}$ & 58 & BANCORPSOUTH INC & 105 & $\begin{array}{l}\text { WESTAMERICA BANC } \\
\text { CORP }\end{array}$ \\
\hline 13 & FIFTH THIRD CORP * & 59 & $\begin{array}{l}\text { FLAGSTAR BANCORP } \\
\text { INC }\end{array}$ & 106 & $\begin{array}{l}\text { NATIONAL BK HOLDS } \\
\text { CORP }\end{array}$ \\
\hline 14 & $\begin{array}{l}\text { GOLDMAN SACHS } \\
\text { GROUP INC * }\end{array}$ & 60 & TRUSTMARK CORP & 107 & $\mathrm{~S} \& \mathrm{~T}$ BANCORP INC \\
\hline 15 & MORGAN STANLEY * & 61 & $\begin{array}{l}\text { CATHAY GENERAL } \\
\text { BANCORP }\end{array}$ & 108 & BANNER CORP \\
\hline 16 & $\begin{array}{l}\text { REGIONS FINANCIAL } \\
\text { CORP * }\end{array}$ & 62 & $\begin{array}{l}\text { OLD NATIONAL BAN- } \\
\text { CORP }\end{array}$ & 109 & $\begin{array}{l}\text { CENTRAL PACIFIC } \\
\text { FINANCIAL }\end{array}$ \\
\hline 17 & $\begin{array}{l}\text { NORTHERN TRUST } \\
\text { CORP } *\end{array}$ & 63 & $\begin{array}{l}\text { WESTERN ALLIANCE } \\
\text { BANC }\end{array}$ & 110 & BANCORP \\
\hline 18 & $\begin{array}{l}\text { ALLY FINANCIAL CORP } \\
*\end{array}$ & 64 & $\begin{array}{l}\text { INTL BANCSHARES } \\
\text { CORP }\end{array}$ & 111 & $1^{\mathrm{ST}}$ SOURCE CORP \\
\hline 19 & M\&T BANK CORP * & 65 & $\begin{array}{l}\text { CAPITOL FED FINAN- } \\
\text { CIAL }\end{array}$ & 112 & $\begin{array}{l}\text { SIMMONS FIRST NAT } \\
\text { CORP }\end{array}$ \\
\hline 20 & KEYCORP & 66 & $\begin{array}{l}\text { FULTON FINANCIAL } \\
\text { CORP }\end{array}$ & 113 & TRUSTCO BANK CORP/NY \\
\hline 21 & $\begin{array}{l}\text { DISCOVER FINANCIAL } \\
\text { SERV. * }\end{array}$ & 67 & $\begin{array}{l}\text { NATIONAL PENN BANC- } \\
\text { SHARE }\end{array}$ & 114 & WILSHIRE BANCORP INC. \\
\hline 22 & COMERICA INC * & 68 & $\begin{array}{l}\text { PROVIDENT FINANCIAL } \\
\text { SVSC }\end{array}$ & 115 & $\begin{array}{l}\text { SANDY SPRING BANCORP } \\
\text { INC. }\end{array}$ \\
\hline 23 & $\begin{array}{l}\text { HUNTINGTON BANC- } \\
\text { SHARES * }\end{array}$ & 69 & $\begin{array}{l}\text { COLUMBIA BANKING } \\
\text { SYSTEM }\end{array}$ & 116 & $\begin{array}{l}\text { SERVISFIRST BANC- } \\
\text { SHARES }\end{array}$ \\
\hline 24 & FIRST REPUBLIC BANK & 70 & $\begin{array}{l}\text { FIRST INTERSTATE } \\
\text { BANCSYS }\end{array}$ & 117 & $\begin{array}{l}\text { NEW YORK CMNTY } \\
\text { BANCORP }\end{array}$ \\
\hline 25 & $\begin{array}{l}\text { FIRST NIAGARA FINAN- } \\
\text { CIAL GRP }\end{array}$ & 71 & $\begin{array}{l}\text { GLACIER BANCORP, } \\
\text { INC. }\end{array}$ & 118 & $\begin{array}{l}\text { YADKIN FINANCIAL } \\
\text { CORP }\end{array}$ \\
\hline 26 & SVB FINANCIAL GROUP & 72 & NBT BANCORP INC & 119 & BNC BANCORP \\
\hline 27 & $\begin{array}{l}\text { PEOPLES UNITED } \\
\text { FINANCIAL }\end{array}$ & 73 & STERLING BANCORP & 120 & AMERIS BANCORP \\
\hline 28 & CITY NATIONAL CORP & 74 & $\begin{array}{l}\text { UNITED COMMUNITY } \\
\text { BANKS }\end{array}$ & 121 & HANMI FIN CORP \\
\hline 29 & KEYCORP * & 75 & $\begin{array}{l}\text { COMMUNITY BANK } \\
\text { SYSTEM }\end{array}$ & 122 & $\begin{array}{l}\text { GREAT SOUTHERN BAN- } \\
\text { CORP }\end{array}$ \\
\hline 30 & BOK FINANCIAL CORP & 76 & $\begin{array}{l}\text { CHEMICAL FINANCIAL } \\
\text { CORP }\end{array}$ & 123 & FIRST NBC BHC \\
\hline 31 & EAST WEST BANCORP & 77 & $\begin{array}{l}\text { HOME BANCSHARES, } \\
\text { INC. }\end{array}$ & 124 & REPUBLIC BANCORP \\
\hline 32 & SIGNATURE BANK & 78 & CVB FINANCIAL CORP & 125 & TRICO BANCSHARES \\
\hline 33 & $\begin{array}{l}\text { CULLEN/FROST BANK- } \\
\text { ERS INC }\end{array}$ & 79 & $\begin{array}{l}\text { UNION BANKSHARES } \\
\text { CORP }\end{array}$ & 126 & $\begin{array}{l}\text { CENTERSTATE BANKS } \\
\text { INC. }\end{array}$ \\
\hline 34 & $\begin{array}{l}\text { SYNOVUS FINANCIAL } \\
\text { CORP }\end{array}$ & 80 & BBCN BANCORP INC & 127 & FIRST BUSEY CORP \\
\hline
\end{tabular}




\begin{tabular}{|c|c|c|c|c|c|}
\hline \# & BHC Name & \# & BHC Name & \# & BHC Name \\
\hline 35 & $\begin{array}{l}\text { ASSOCIATED BANC- } \\
\text { CORP }\end{array}$ & 81 & PARK NATIONAL CORP & 128 & CENTURY BANCORP INC \\
\hline 36 & $\begin{array}{l}\text { FIRST HORIZON } \\
\text { NATIONAL CO }\end{array}$ & 82 & $\begin{array}{l}\text { FIRST FINANCIAL BAN- } \\
\text { CORP }\end{array}$ & 129 & $\begin{array}{l}\text { COMMUNITY TR BAN- } \\
\text { CORP INC }\end{array}$ \\
\hline 37 & FIRSTMERIT CORP & 83 & CUSTOMERS BC & 130 & $\begin{array}{l}\text { LAKELAND BANCORP } \\
\text { INC }\end{array}$ \\
\hline 38 & $\begin{array}{l}\text { UMPQUA HOLDINGS } \\
\text { CORP }\end{array}$ & 84 & CAPITAL BK FNCL CORP & 131 & WASHINGTON TR BC INC \\
\hline 39 & $\begin{array}{l}\text { PROSPERITY BANC- } \\
\text { SHARES INC }\end{array}$ & 85 & $\begin{array}{l}\text { INDEPENDENT BANK } \\
\text { Corp }\end{array}$ & 132 & HERITAGE FC \\
\hline 40 & CIT GROUP & 86 & POPULAR INC & 133 & CARDINAL FC \\
\hline 41 & HANCOCK HOLDING CO & 87 & BOSTON PRIVATE FINL & 134 & $\begin{array}{l}\text { FIDELITY SOUTHERN } \\
\text { CORP }\end{array}$ \\
\hline 42 & TCF FINANCIAL CORP & 88 & BANCFIRST CORP & 135 & $\begin{array}{l}\text { WINTRUST FINANCIAL } \\
\text { CORP }\end{array}$ \\
\hline 43 & BANKUNITED INC & 89 & $\begin{array}{l}\text { BERKSHIRE HILLS } \\
\text { BANCORP }\end{array}$ & 136 & $\begin{array}{l}\text { DIME COMMUNITY } \\
\text { BANCS }\end{array}$ \\
\hline 44 & $\begin{array}{l}\text { ZIONS BANCORPORA- } \\
\text { TION * }\end{array}$ & 90 & $\begin{array}{l}\text { LEGACYTEXAS FNCL } \\
\text { GRP }\end{array}$ & 137 & MAINSOURCE FNCL GRP \\
\hline 45 & $\begin{array}{l}\text { VALLEY NATIONAL } \\
\text { BANCORP }\end{array}$ & 91 & $\begin{array}{l}\text { FIRST COMMONWLTH } \\
\text { FINL }\end{array}$ & 138 & COBIZ FNCL INC \\
\hline \multirow[t]{2}{*}{46} & SUSQUEHANNA BANC- & 92 & PINNACLE FNCL PTNR & 139 & BRYN MAWR BK CORP \\
\hline & & 93 & $\begin{array}{l}\text { BANC OF CALIFORNIA } \\
\text { INC. }\end{array}$ & 140 & BANK MUTUAL CORP \\
\hline
\end{tabular}

Source Author, based on US Federal Reserve data (http://www.federalreserve.gov/releases/lbr/current/) All SIFIs (Too-Big-to-Fail) BHCs are designated with $\mathrm{a}^{*}$

\section{Appendix 3}

Principal Component Analysis (PCA) ${ }^{15}$ and CEO Power as an Alternative Specification

This table reports the supplementary material associated with the creation of a CEO Power, a new variable which seeks to proxy the strength of the CEO as an alternative specification to in the baseline results to Duality. Four new variables ${ }^{16}$ are collected and

\footnotetext{
15 PCA produces a new variable called CEO Power, which is made up of the components of the index. The newly formed variables, called principal components, are by construction orthogonally related and the first linear combination that explains the maximum variation in the variables (Lingel and Sheedy 2012). The above value of 0.3059 is noted for this measure. The first eigenvector defines the relevant weightings. The index that results facilitates the reduction in variables used to one measure. The weighting assigned to each index component is determined by the eigenvector. The benefit of PCA is it facilitates construction of the new CEO proxy variable without having to arbitrarily assign weightings to each variable.

${ }^{16}$ CEO Power is an index created by applying Principal Component Analysis (PCA) to underlying CEO power variables, namely CEO Recruited Inside, CEO Busyness, CEO Education, and CEO Total Annual Compensation Mix. CEO Recruited Inside is a dummy variable assigned 1 (otherwise 0) if the CEO directly preceding role was within the BHC (or not). CEO Busyness is a variable the measures the number of total board memberships (including the BHC) held by the CEO. CEO Education is dummy variable assigned a value of 1 (otherwise 0) if the CEO's educational credentials meets those defined by Güner et al. (2008). CEO Total Compensation Mix is the total USD compensation reported for the CEO from salary, bonus, stock and other benefits including benefits as reported by Morningstar and discussed in Larcker and Tayan (2017).
} 
measured to produce the CEO Power variable, namely CEO Recruited Inside reflecting the strength of networks developed over time (Pathan 2009), CEO Busyness illustrating endorsement benefits as noted by Nguyen et al. (2015) and Cooper and Uzun (2012), CEO Education (Güner et al. 2008) and CEO Total Annual Compensation Mix (Larcker and Tayan 2017). All variables have been collected via BoardEx other than the final variable which was collected via Morningstar. The log value of this variable is employed in the model and all explanatory variables are lagged in this model as in the baseline model reported in Table 3.

\begin{tabular}{|c|c|c|c|c|c|}
\hline \multicolumn{6}{|l|}{ Panel I } \\
\hline Component & Eigenvalue & \multicolumn{2}{|l|}{ Difference } & Proportion & Cumulative \\
\hline PC1 & 1.22369 & \multicolumn{2}{|l|}{0.0957383} & 0.3059 & 0.3059 \\
\hline PC2 & 1.12795 & \multicolumn{2}{|l|}{0.276492} & 0.2820 & 0.5879 \\
\hline PC3 & 0.851461 & \multicolumn{2}{|l|}{0.0545666} & 0.2129 & 0.8008 \\
\hline $\mathrm{PC} 4$ & 0.796895 & . & & 0.1992 & 1.0000 \\
\hline \multicolumn{6}{|l|}{ Panel II: Eigenvalues } \\
\hline Variable & $\mathrm{PC} 1$ & $\mathrm{PC} 2$ & PC3 & $\mathrm{PC} 4$ & Unexplained \\
\hline CEO recruited inside & 0.6527 & -0.1997 & 0.3847 & -0.6214 & 0 \\
\hline CEO busyness & 0.4781 & -0.5646 & -0.0180 & 0.6726 & 0 \\
\hline CEO education & 0.2692 & 0.6864 & 0.5448 & $0.3994 \mid$ & 0 \\
\hline $\begin{array}{l}\text { CEO total annual compe } \\
\text { sation mix }\end{array}$ & en- 0.5224 & 0.4126 & -0.7449 & -0.0450 & 0 \\
\hline
\end{tabular}

\section{Appendix 4: difference-in-means}

\begin{tabular}{lllll}
\hline & SIFIs & Non-SIFIs & $t$ test & $p$-value \\
\hline Efficiency ratio & 64.871 & 63.291 & -1.2 & 0.221 \\
NPLTL & 0.81 & 0.88 & 0.95 & 0.342 \\
Tier1 & 12.74 & 13.658 & 2.5 & 0.013 \\
Tail risk & -29.294 & -18.139 & 5.05 & 0 \\
Z-score & 0.622 & 0.754 & 0.15 & 0.867 \\
Duality & 0.807 & 0.448 & -8.05 & 0 \\
CEO board tenure & 1.811 & 2.201 & 4.65 & 0 \\
CEO shareholding & 17.39 & 15.791 & -12.3 & 0 \\
TARP & 8.46 & 4.765 & -34.05 & 0 \\
Board size & 13.178 & 11.728 & -5.05 & 0 \\
BHC size & 12.344 & 9.036 & -42.55 & 0 \\
Deposits & 64.469 & 76.856 & 13.5 & 0 \\
Total loans & 51.285 & 67.884 & 12.45 & 0 \\
Board non-insider & 41.17 & 24.13 & -.95 & 0.338 \\
Risk committee & 0.887 & 0.645 & -5.7 & 0 \\
Risk appetite & 0.546 & 0.197 & -9.05 & 0 \\
\hline
\end{tabular}




\begin{tabular}{llllc}
\hline & SIFIs & Non-SIFIs & $t$ test & $p$-value \\
\hline CRO centrality & 0.281 & 0.241 & -1.45 & 0.148 \\
CRO tenure & 12.472 & 7.702 & -6.15 & 0 \\
\hline
\end{tabular}

Notes This table presents different mean values for Non-SIFIs and SIFIs

\section{References}

Abels P, Martelli J (2013) Duality: how many hats are too many? Corp Gov 13(2):135-147

Acharya V, Shin H, Yorulmazer T (2011) Crisis resolution bank liquidity. Rev Financ Stud 24:2166-2205

Adams R (2012) Governance and the financial crisis. Int Rev Financ 12(1):7-38

Adams M, Jiang W (2015) Do outside directors influence the financial performance of risk-taking firms? evidence from the UK insurance industry. J Bank Financ 64(2016):36-51

Adams R, Mehran H (2003) Is corporate governance different for bank holding companies? FRBNY Econ Policy Rev 9(1):123-142

Adams R, Mehran H (2012) Bank board structure and performance: evidence for large bank holding companies. J Financ Intermed 21(2012):243-267

Aebi V, Sabato G, Schmid M (2012) Risk management, corporate governance, and bank performance in the financial crisis. J Bank Financ 36(12):3213-3226

AFSCME Pension Fund (2013) Major investors call on JP Morgan Chase to name independent board chairman. https://www.afscme.org/news/press-room/press-releases/2013/major-investors-call-on-jpmor gan-chase-to-name-independent-board-chair (Accessed 12 September, 2015)

Akbar S, Kharabsheh B, Poletti-Hughes, Shah S (2017) Board structure and corporate risk-taking in the UK financial sector. Int Rev Financ Anal 50(2017):101-110

Akhigbe A, Stevenson B (2010) Profit efficiency in US BHCs: effects of increasing non-traditional revenue sources. Q Rev Econ Financ 50(2010):132-140

Akhigbe A, Martin A, Whyte A (2015) Dodd-Frank and risk in the financial services industry. Rev Q Financ Account 2016(47):396-415

Akhigbe A, McNulty J, Stevenson B (2016) Additional evidence on transparecy and bank financial performance. Rev Financ Econ 32(2017):1-6

Allam B (2018) The impact of board characteristics and ownership identiy on agency costs and firm performance: UK evidence. Corp Gov 18(6):1147-1176

Altman E (1968) Financial ratios, discriminant analysis and the prediction of corporate bankruptcy. J Financ 22:550-612

Amoozegar A, Pukthuanthong K, Walker T (2017) On the role of the chief risk officer and the rise of the risk committee in insuring financial institutions against litigation. Manag Financ 43(1):19-43

Andersson L, Nestor S (2018) Governance of the 25 larget European banks a decade after the crisis. https ://corpgov.law.harvard.edu/2018/06/11/governance-of-the-25-largest-european-banks-a-decade-after -the-crisis/ (Accessed 3 October 2018)

Antonakis J, Bendahan S, Jacquart P, Lalive R (2010) On making casual claims: a review and recommendations. Leadersh Quart 21(2010):1086-1120

APRA (2018) Prudential standard CPS 510 governance. consultation draft. https://www.apra.gov.au/sites/ default/files/CPS\%2520510\%2520Governance\%2520including\%2520PHIs.pdf (Accessed 11 November 2018)

Arellano M, Bover O (1995) Another look at the instrumental variables estimation of error-components models. J Econom 1(68):29-51

Bai G, Elyasiani E (2013) Bank stability and managerial compensation. J Bank Finance 37(3):799-813

Bank Director (2016) The 2016 risk practices survey. http://www.bankdirector.com/issues/risk/2016risk-practices-survey-banks-beef-up-on-cybersecurity/ (Accessed: 5 August 2016)

Barth J (2015) Examining the designation and regulation of BHC SIFIs. The statement before the house financial services committee, U.S. House of representatives.http://financialservices.house.gov/ calendar/?EventTypeID $=($ Accessed: 1 February 2016)

Barth J, Sau M (2015) Designating bank SIFIs: an arbitrary threshold for risk. https://assets1b.milke ninstitute.org/assets/Publication/Viewpoint/PDF/Designation-of-Bank-SIFIs-WP-FORMATTED. pdf (Accessed 22 January 2016) 
Basel (2015) Basel committee on banking supervision guidelines. corporate governance principles for banks. http://www.bis.org/bcbs/publ/d328.htm (Accessed: 25 August 2015)

Battaglia F, Gallo A (2015) Risk governance and Asian bank performance: an empirical investigation over the financial crisis. Emerg Mark Rev 30(2015):1-16

Bebchuk L, Fried J, Walker D (2002) Managerial power and rent extraction in the design of executive compensation. Discussion Paper No. 366. Harvard Law School. Available at: http://www.law.harvard.edu/ programs/olin_center/. Accessed 1 June 2018

Belghitar Y, Clark E (2012) The effect of CEO risk appetite on firm volatility: an empirical analysis of financial firms. Int J Econ Bus 2012:1-33

Beltratti A, Paladino G (2015) Bank leverage and profitability: evidence from a sample of international banks. Rev Financ Econ 27(2015):46-57

Beltratti A, Stulz R (2012) The credit crisis around the globe: why did some banks perform better? J Financ Econ 105(1):1-17

Berger A, Bouwman C (2013) How does capital affect bank performance during financial crises?. J Financ Econ 109(2013):146-176

Berger A, El Ghoul S, Guedhami O, Roman R (2016). Internationalization and bank risk. Manag Sci (Forthcoming). 1-z25

Bhagat S, Bolton B, Romano R (2008) The promise and peril of corporate governance indices. Columbia Law Rev 108(8):1801-1882

Bhagat S, Bolton B, Lu J (2015) Size, leverage and risk-taking of financial institutions. J Bank Financ 59(2015):520-537

Bharati R, Jia J (2018) Do bank CEOs really increase risk in vega? evidence from a dynamic panel GMM specification. J Econ Bus 99(2018):39-52

Black L, Hazelwood L (2012) The effect of TARP on risk-taking. board of governors of the federal reserve system. https://www.federalreserve.gov/pubs/ifdp/2012/1043/ifdp1043.pdf (Accessed 18 January 2015)

Black B, Kim W (2012) The effect of board structure on firm value: a multiple identification strategy approach using Korean data. J Financ Econ 104(2012):203-226

Blundell R, Bond S (1998) Initial conditions and moment restrictions in dynamic panel data models. J Econom 87:115-143

BoardEx (2016) http://corp.boardex.com/academics/ (Accessed: 14 October 2016)

Boone A, Field L, Karpoff J, Raheja C (2007) The determinants of corporate board size and composition: an empirical analysis. J Financ Econ 85:66-101

Booth J, Cornett M, Tehranian H (2002) Boards of directors, ownership, and regulation. J Bank Finance 2002:1973-1996

Bouwens J, Verriest A (2014) Putting skin-in-the-game. managerial ownership and bank risk-taking. Harv Bus Rev 14(070):1-52

Boyd B (1995) Duality and firm performance: a contingency model. Strateg Manag J 16:301-312

Brick I, Palmon O, Wald J (2006) CEO compensation, director compensation and firm performance: evidence from cronyism. J Corp Financ 12:403-423

Brown M (2010) Understanding the new financial reform legislation: The Dodd-Frank wall street reform and consumer protection act. https://www.mayerbrown.com/public_docs/Final-FSRE-Outline.pdf (Accessed 2 November 2016)

Bushman R, Davidson R, Dey A, Smith A (2018) CEO materialism: risk control, culture and tail-risk. J Account Econ 65(208):191-220

Byrd J, Cooperman E (2010) Director tenure and the compensation of bank CEOs. Manag Financ 36(2):86-102

Byrd J, Fraser S, Lee D, Tartaroglu S (2012) Are two heads better than one? evidence from the thrift crisis. J Bank Financ 2012:957-967

Carty R, Weiss G (2012) Does duality affect corporate performance? evidence from the US banking crisis. J Financ Regul Compliance 20(1):26-40

Central Bank of Ireland (2015) Corporate governance requirements for credit institutions. https://www.centr albank.ie/docs/default-source/regulation/codes/gns-4-1-7-corgovreq-credinstits2015.pdf?sfvrsn=4 (Accessed 21 August 2017)

Charkham J (2003) Guidance for directors of banks. Global Corporate Governance Forum/The World Bank. pp. 1-51

Chen C, Al-Najjar B (2012) The determinants of board size and independence: evidence from China. Int Bus Rev 21:831-846

Chen Z, Ebrahim A (2018) Turnover threat and CEO risk taking behaviour in the banking industry. J Bank Financ 96(2018):87-105 
Chen H, Lin K (2016) How do banks make the trade-offs among risks? the role of corporate governance. J Bank Financ 2016:1-31

Chen C, Lin B, Yi B (2008) Duality and firm performance-an endogenous issue. Corp Ownersh Control 6(1):58-65

Chen Y, Shen C, Kao L, Yeh C (2018) Bank liquidity risk and performance. Rev Pac Basin Financ Mark Policies 21(1):1850007. https://doi.org/10.1142/S0219091518500078

Chiaramonte L, Liu F, Poli F, Zhou M (2016) How accurately can Z-score predict bank failure? Finanic Mark Inst Instrum 23(2):333-360

Chung K, Pruitt S (1996) Executive ownership, corporate value and executive compensation: a unifying framework. J Bank Financ 20:1135-1160

Claessens S (2014) Capital and liquidity requirements: a review of the issues and literature. Yale J Regul 31:735-772

Clark T (2004) Cycles of crisis and regulation: the enduring agency and stewardship problem of corporate governance. Corp Gov Int Rev 12(2):153-172

Coles J, Daniel N, Naveen L (2008) Boards: does one size fit all? J Financ Econ 51:371-406

Congressional Research Service.(2017) Bank systemic risk regulation and the $\$ 50$ billion threshold in the Dodd-Frank Act. https://fas.org/sgp/crs/misc/R45036.pdf (Accessed 29 December 2017)

Cooper E, Uzun H (2012) Directors with a full plate: the impact of busy directors on bank risk. Manag Financ 38(6):571-586

Cornett M, McNutt J, Tehranian H (2009) Corporate governance and earnings management at large US BHCs. J Corp Financ 15(2009):412-430

Cornett M, McNutt J, Tehranian H (2010) The financial crisis, internal corporate governance, and the performance of publically traded US BHCs. http:ssrn.com/abstract $=1476969$ (Accessed: 19 January 2015)

Cornett M, Erhemjamts O, Tehranian H (2016) Greed or good deeds: an examination of the relationship between CSR and financial perforamnce of US banks. J Bank Financ 70(2016):137-160

Custodio C, Metzger D (2014) Financial expert CEOs: CEO's work experience and firm's financial policies. J Financ Econ 114(1):125-154

de Andres P, Vallelado E (2008) Corporate governance in banking: the role of the board of directors. J Bank Financ 32(12):2570-2580

de Haan J, Vlahu R (2015) Corporate governance of banks: a survey. Journal of Economic Surveys. 00:1-50

DeBoskey D, Luo Y, Zhou L (2019) CEO power, board oversight and earnings announcement tones. Rev Quant Financ Acc 52:657-680. https://doi.org/10.1007/s11156-018-0721-X

Delis M, Kouretas G (2011) Interest rates and bank risk-taking. J Bank Financ 35(4):840-855

Dermine J (2013) Bank regulations after the global financial crisis, good intentions and unintended evil. http://faculty.insead.edu/jean-dermine/documents/RegulationsAfterCrisis2013-March.pdf (Accessed: 22 March 2015)

Dewatripont M, Freixas X (2012) The crisis aftermath: new regulatory paradigms. http://www.voxeu.org/ epubs/cepr-reports/crisis-aftermath-new-regulatory-paradigms (Accessed: 29 April 2015)

Dodd-Frank Act (2010) The wall street reform and consumer protection act. https://www.govtrack.us/congr ess/bills/111/hr4173/text (Accessed 15 December 2015)

Donaldson L, Davis J (1991) Stewardship theory or agency theory: CEO governance and shareholder returns. Aust J Manag. https://doi.org/10.1177/031289629101600103

Dupire M, Slagmulder R (2018) Risk governance of financial institutions: the effect of ownership structure and board independence. Financ Res Lett 28(2018):43-75. https://doi.org/10.1016/j.frl.2018.05.001

Duru A, Iyengar R, Zempelli E (2016) The dynamic relationship between duality and performance: the moderating role of board independence. J Bus Res 69(2016):4269-4277

Duchin R, Sosyura D (2014) Safer ratios, risk portfolios: bank's response to government aid. J Financ Econ 113(2104):1-28

Egly P, Johnk D, Mollick A (2018) Bank net interest margins, the yield curve and the financial crisis. Rev Financ Econ 2018(36):12-32

Elamer A, Al Hares A, Ntim C, Benyazid I (2018) The corporate governance-risk-taking nexus: evidence from insurance companies. Int J Ethics Syst 34(4):493-503

Ellul A (2015) The role of risk management in corporate governance. Annu Rev Financ Econ 7:1-17

Ellul A, Yerramilli V (2013) Stronger risk controls, lower risk: evidence from U.S. bank holding companies. J Financ 68(5):1757-1803

Enache L, Hussainey K (2019) The substitutive relation between voluntary disclosure and corporate governance in their in their effects of firm performance. Rev Quant Financ Acc 54(2):1-33 
European Banking Association (2011) EBA guidelines on internal governance. GL 44. https://www.eba. europa.eu/documents/10180/103861/EBA-BS-2011-116-final-EBA-Guidelines-on-Internal-Gover nance-\%282\%29_1.pdf (Accessed 31 August 2014)

Fahlenbrach R, Stulz R (2011) Bank CEO incentives and the credit crisis. J Financ Econ 99(1):11-26

Faleye O, Krishnan K (2010) Risky lending: does bank corporate governance matter?.http://ssrn.com/ abstract $=1661837$ (Accessed on September 1, 2015)

Faleye O, Hoitash R, Hoitash U (2011) The costs of intense board monitoring. J Financ Econ 2011:160-181

Faleye O, Hoitash R, Hoitash U (2017) Industry expertise on corporate boards. Rev Quant Financ Acc 2018(50):441-479. https://doi.org/10.1007/s11156-017-0635-z

Faleye O (2015) The costs of a (nearly)fully independent board. J Empir Financ 32:49-62

Fama E, Jensen M (1983) Separation of ownership and control. J Law Econ XXVI:1-31

FDIC (2018) Statement made by Jelena McWilliams, Chairman, FDIC: proposed changes to applicability thresholds for regulatory capital requirements and liquidity requirements. https://www.fdic. gov/news/news/speeches/spnov2018b.html?source=govdelivery\&utm_medium=email\&utm_ source $=$ govdelivery $($ Accessed 21 November 2018)

Federal Register (2014a) OCC guidelines establishing heightened standards for certain large insured national banks and federally insured savings associations. 79(176). Available at: https://www.gpo. gov/fdsys/pkg/FR-2014-09-11/pdf/2014-21224.pdf (Accessed: 16 December 2015)

Federal Register (2014b) Enhanced prudential standards for BHCs and FBOs-Final Rule. 79(59). https ://www.gpo.gov/fdsys/pkg/FR-2014-03-27/pdf/2014-05699.pdf (Accessed: 16 December 2015)

Federal Reserve System Board of Governors (2016) Largest US BHCs. http://www.federalreserve.gov/ releases/lbr/current/ (Accessed: 27 January 2016)

Ferreira D, Kirchmaier T, Metzger D (2012) Boards of banks. http://ssrn.com/abstract=1620551 (Accessed: 4 January 2015)

Financial Crisis Inquiry Report (2011) The final report of the national commission on the causes and the financial and economic crisis in the US. http://www.gpo.gov/fdsys/pkg/GPO-FCIC/pdf/GPOFCIC.pdf (Accessed: 16 August 2015)

Financial Times (2015a) Shed no tears for slow demise of the CEO chair role. https://www.ft.com/conte nt/13b9257e-f563-11e4-8c83-00144feab7de (Accessed 3 March 2016)

Finkelstein S, D'Aveni R (1994) Duality as a double-edged sword: how boards of direc- tors balance entrenchment avoidance and unity of command. Acad Manag J 37:1079-1089

Fiordelisi F, Marques-Ibanez D, Molyneux P (2011) Efficiency and risk in European banking. J Bank Financ 35(2011):1315-1326

Flannery M (1998) Using market information in prudential supervision: a review of US empirical evidence. J Money Credit Bank 30:273-305

Florackis C (2008) Agency costs and corporate governance mechanisms evidence for UK firms. Int $\mathbf{J}$ Manag Financ 4(1):37-59

Fortin R, Goldberg G, Roth G (2010) Bank risk-taking at the onset of the current banking crisis. Financ Rev 45(4):891-913

Francis B, Hasan I, Wu Q (2012) Do corporate boards matter during the current financial crisis? Rev Financ Econ 21(2012):39-52

FRC (2010) The UK corporate governance code. https://www.frc.org.uk/getattachment/31631a7a-bc5c4e7b-bc3a-972b7f17d5e2/UK-Corp-Gov-Code-June-2010.pdf (Accessed 21 December 2014)

FSB (2013) Thematic review on risk governance. http://www.financialstabilityboard. org/2013/02/r_130212/ (Accessed: 1 July 2015)

Gangopadhyay P, Yook K, Haley J (2018) Bank bailouts and corporate insider trading during the financial crisis of 2007-2009). Rev Quant Financ Acc 2019(52):35-83. https://doi.org/10.1007/s1115 6-018-0702-0

Gao, Y., Liao, S., and Wang, X. (2013). The Economic Impact of the Dodd-Frank Act upon SIFIs: Evidence from Market Reactions. Available at: file://Users//Downloads/SSRN-id1919630\%20(1).pdf (Accessed: 10 August 2016)

Goetz M (2018) Competition and bank stability. J Financ Intermed 35(2018):57-69

Gontarek W (2016) Risk governance of financial institutions: the growing importance of risk appetite and culture. J Risk Manag Financ Inst 9(2):120-129

Gontarek W, Belghitar Y (2018) Risk governance: examining its impact upon bank performance \& risktaking in US BHCs. Financ Mark Inst Instrum. https://doi.org/10.1111/fmii.12103

Grove H, Patelli L, Victoravich L, Xu P (2011) Corporate governance and performance in the wake of the financial crisis: evidence from US commercial banks. Corp Gov: Int Rev 19(5):418-436 
Gontarek W, Bender R (2018) Examining risk governance practices in global financial institutions: the adoption of risk appetite statements. J Bank Regul 20:1-13. https://doi.org/10.1057/s41261-018-0067-2

Güner A, Malmendier U, Tate G (2008) Financial expertise of directors. J Financ Econ 88(2008):323-354

Hagendorff J, Vallascas F (2011) CEO pay incentives and risk-taking: evidence from bank acquisitions. J Corp Financ 17(4):854-870

Hardwick P, Adams M, Zou H (2011) Board characteristics and profit efficiency in the UK life insurance industry. Journal of Business Finance \& Accounting. 38(7):987-1015

Hayes N (2013) Governance for strengthened risk management. RMA J 95(8):23-25

Hermalin BE, Weisbach MS (2003) Boards of directors as an endogenously determined institution: a survey of the economic literature. Econ Policy Rev 9:7-26

Hines C, Peters G (2015) Voluntary risk management committee formation: determinants and short-term outcomes. J Account Public Policy 34(2015):267-291

Ho P, Huang C, Lin C, Yen J (2016) CEO overconfidence and financial crisis: evidence from bank lending and leverage. J Financ Econ 120(2016):194-210

Hogan T, Meredith N, Pan X (2017) Evalating risk-based capital regulation. Rev Financ Econ 2017:1-9

Holmquist E (2014) Why you need a risk committee. RMA J 96:18-21

Huang H, Dao M, Sun W (2017) The timeliness of financial reporting and fair values: evidence from US Banks. Rev Pac Basin Financ Mark Policies 20(1):1750006. https://doi.org/10.1142/S021909151 7500060

Iqbal J, Vähämaa S (2018) Managerial risk-taking incentives and the systemic risk of financial institutions. Rev Quant Financ Account 53:1-30. https://doi.org/10.1007/s11156-018-0780-z

Iselin M (2016) Estimating the potential impact of requiring a stand -alone board level risk committee. http://papers.ssrn.com/sol3/papers.cfm?abstract_id=2761556 (Accessed: 15 August 2016)

Jacewitz S, Kupiec P (2012) Community bank efficiency and economies of scale. FDIC Publ 2012:1-12

Jensen MC (1993) The modern industrial revolution, exit, and the failure of internal control systems. J Financ 48(3):831-880

Jensen M, Meckling W (1995) Specific and general knowledge and organizational structure. Available at: https://papers.ssrn.com/sol3/papers.cfm?abstract_id=6658. Accessed 14 Mar 2019

John K, De Masi S, Paci (2016) Corporate governance in banks. Corp Gov Int Rev 24(3):303-321

Kanas, A. and Zervopoulos, P. (2019). Systemic risk shifting in US commercial banks. Review of Quantitative Finance and Accounting. pp. 1 - 23. https://doi.org/10.1007/s11156-019-00797-5

Kashyap A, Rajan R, Stein J (2008) Re-thinking capital regulation. http://scholar.harvard.edu/stein/publi cations/rethinking-capital-regulation (Accessed: 30 April 2015)

Keffala M (2017) Analyzing the effect of derivatives on the financial soundness of commercial banks in Italy: an approach based on the CAMELs framework. Rev Financ Econ 2018(36):267-283

Keys B, Mukherjee T, Seru A, Vig V (2009) Financial regulation and securitization: evidence from subprime loans. J Monet Econ 56(2009):700-720

Kim E, Lu Y (2011) CEO ownership, external governance and risk-taking. J Financ Econ 102(2011):272-292

King T, Srivastav A, Williams J (2016) What's in an education? implications of CEO education upon bank performance. J Corp Financ 37:287-308

Kozubovska M (2017) The effect of US BHCs exposure to ABCP conduits on the information opacity and risk. Res Int Bus Financ 39(2017):530-545

Krause R, Semadeni M, Cannella A (2014) Duality: a review and research agenda. J Manag 40:256-286

Kupeic P, Lee Y (2012) What factors explain differences in return on assets among community banks? FDIC Working Paper. pp 1-16

Laeven L, Levine R (2009) Bank governance, regulation and risk-taking. J Financ Econ 00(0000):2-43

Landier A, Sauvagnat J, Sraer D, Thesmar D (2013) Bottom-up corporate governance. Rev Financ 17:161-201

Larcker D, Rusticus T (2009) On the use of instrumental variables in accounting research. J Account Econ 49(2010):186-205

Larcker D, Tayan B (2016) Chairman and CEO: the controversy over board leadership structure. Stanford University closer look series. https:/www.gsb.stanford.edu/sites/gsb/files/publication-pdf/cgri-close r-look-58-independent-chair.pdf (Accessed 31 December 2016)

Larcker D, Tayan B (2017) CEO total compensation. Stanford university graduate school of business corporate research. https://www.gsb.stanford.edu/sites/gsb/files/publication-pdf/cgri-quick-guide-17-ceocompensation-data.pdf (Accessed 19 December 2017)

Lasfer M (2006) The interrelationship between managerial ownership and board structure. J Bus FinancAccount 33(7-8):1006-1033 
Lee C-F, Liang W, Lin F-L, Yang Y (2016a) Applications of simultaneous equations in finance research: methods and empirical results. Rev Quant Financ Acc 2016(47):943-971

Lee C, Liang W, Lin F, Yang Y (2016b) Applications of simultaneous equations in finance research: methods and empirical results. Rev Quant Financ Account 47:943-971. https://doi.org/10.1007/ s11156-015-0526-0

Leventis S, Dimitropoulos P (2012) The role of corporate governance in earnings management. Experience from US banks. J Appl Account Res 13(2):161-171

Lewellyn K, Muller-Kahle M (2012) CEO power and risk-taking: evidence for the subprime industry. Corp Gov Int Rev 20(13):289-307

Li F (2016) Endogeneity in CEO power: a survey and experiment. Invest Anal J 45(3):149-162. https:// doi.org/10.1080/10293523.2016.1151985

Li M, Roberts H (2018) CEO board membership: implications for firm value. Pac Account Rev 30(3):362-370

Linck J, Netter J, Yang T (2008) The determinants of board structure. J Financ Econ 87(2008):308-328

Lingel A, Sheedy E (2012) The influence of risk governance on risk outcomes -international evidence. http://papers.ssrn.com/sol3/papers.cfm?abstract_id=2482168 (Accessed: 28 February 2015)

Liu P, Shao Y, Gu Y (2017) Bank structure and liquidity shocks: evidence from emerging markets during the 2008 financial crisis. Rev Pac Basin Financ Mark Policies 20:3. https://doi.org/10.1142/ S0219091517500151

Lu J, Boateng A (2018) Board composition, monitoring and credit risk in the UK banking industry. Rev Quant Financ Acc 2018(51):1107-1128. https://doi.org/10.1007/s11156-017-0698-X

Macey J, O'Hara M (2016) Bank corporate governance: a proposal for the post-crisis world. FRBNY Econ Policy Rev 85-105

Mamatzakis E, Bermpei T (2015) The effect of corporate governance on the performance of US investment banks. Financ Mark Inst Instrum 1-49

Mamun A, Hassan M (2015) The relationship between board characteristics and performance of BHC before and during the financial crisis. J Econ Financ. https://doi.org/10.1007/s12197-014-9312-4

Mehran H, Morrison A, Shapiro J (2011) Corporate governance and banks: what have we learned from the financial crisis? NY Federal Board Reports. http://www.newyorkfed.org/research/staff_reports/ sr502.pdf (Accessed: 4 January 2015)

Minton B, Taillard J, Williamson R (2014) Do Independence and Financial Expertise of the Board Matter for Risk-taking and Performance? J Financ Quan Anal 49(2):1-66

Misangyi V, Acharya A (2014) Substitutes or complements? a configurational examination of corporate governance mechanisms. Acad Manag J 57(6):1681-1705

Mollah S, Liljeblom E (2016) Governance and bank charactertistics in the credit and sovereign debt crises-the impact of CEO Power. J Financ Stab 27(2016):59-73

Nakano M, Nguyen P (2012) Board size and corporate risk-taking: further evidence from Japan. Corp Gov Int Rev 20(4):369-387

Nguyen T, Locke S, Reddy K (2015) Does boardroom gender diversity matter: evidence from a transitional economy. Int Rev Econ Financ 37:184-202

Nwaeze E, Xu Q, Yin Q (2018) The implications of TARP: evidence from bank performance and CEO pension benefits. J Acc Public Policy 37:458-476

NYT-New York Times (2019) Regulatory move eases post crisis oversight of wall street. https://www. nytimes.com/2019/03/06/business/bank-regulation.html (Access 8 March 2019)

OCC (2014) Office of comptroller of the currency.12 CFR Reports parts 30 and 170. http://www.occ. gov/news-issuances/news-releases/2014/nr-occ-2014-117a.pdf (Accessed: 12

Onali E, Galiakhmetova R, Molyneux P, Torluccio G (2016) CEO Power, government monitoring and bank dividends. J Finanic Intermed 27(2016):89-117

OSFI (2018) Corporate governance: sound business and financial practices. Available at: https://www. osfibsif.gc.ca/Eng/fi-if/rg-ro/gdn-ort/glld/Pages/CG_Guideline.aspx. Accessed 16 Apr 2018

Palia D (2001) The endogeneity of managerial compensation in firm valuation: a solution. Rev Financ Stud. 14(3):735-764

Pathan S (2009) Strong boards, CEO power and bank risk-taking. J Bank Financ 33(7):1340-1350

Pi L, Timme S (1993) Corporate control and bank efficiency. J Bank Financ 17(2-3):515-530

Radic N, Fiordelisi N, Girardone C (2012) Efficiency and risk-taking in pre-crisis investment banks. J Financ Serv Res 41(1):81-101

Rediker K, Seth A (1995) Board of directors and substitution effect of alterantive governance mechanisms. Strateg Manag J 16:85-99

Sabato G (2009) Financial crisis: wheredid risk management fail? Int Rev Appl Financ Issue Econ 2(2):316-327 
Schäuble J (2019) The impact of external and internal corporate governance mechanisms on agency costs. Corp Gov 19(1):1-22

Senior Supervisors Group-SSG (2008) Observations on risk management practices during the recent market turbulence. https://www.sec.gov/news/press/2008/report030608.pdf (Accessed: 15 January 2015)

Senior Supervisors Group-SSG (2009) Risk management lessons from the global banking crisis of 2008. https://www.sec.gov/news/press/2009/report102109.pdf (Accessed: 15 January 2015)

Shah S, Akbar S, Lui J, Lui Z, Cao S (2017) CEO compensation and bank's risk-taking during pre and post-financial crisis period. Res Int Bus Financ 42(2017):1489-1503

Sheedy E, Griffin B (2017) Risk governance, structures, culture and behaviour: a view from the inside. Corp Gov Int Rev 26(4):4-22

Silva T, Guerrs S, Tabak B, Miranda R (2016) Financial networks, bank efficiency and risk-taking. J Financ Stab 25:247-257

Simpson W, Gleason A (1999) Board structure, ownership, and financial distress in banking firms. Int Rev Econ Financ 8(1999):281-2092

Skala D, Weill L (2015) Does CEO gender drive risk-taking? https://gdrenice2015.sciencesco nf.org/57562/document (Accessed 22 March 2017)

Smith C, Stulz R (1985) The determinants of firm's hedging policies. J Financ Quant Anal 20(4):391-404

Sora A, Natale S (2004) The ethical dilemma of merging the roles of the CEO and chairman of the board. Corp Gov 4(2):64-68

Spong K, Sullivan R (2007) Corporate governance and bank performance. Federal Reserve Bank of Kansas City. https://scholar.google.co.uk/citations?view_op=view_citationand hl=enand user $=$ Y2HDLbgAAAAJand citation_for_view $=$ Y2HDLbgAAAAJ:LkGwnXOMwfcC (Accessed: 14 January 2015)

Srivastav A, Hagendorff J (2016) Corporate governance and bank risk-taking. Corp Gov Int Rev 24(3):334-345

Stock J, Yogo M (2005) Testing for weak instruments in linear IV regression. In: Identification and inferencefor econometric models. Cambridge University Press, New York

Stock J, Wright J, Yogo M (2002) A survey of weak instruments and weak identification in generalized method of moments. J Bus Econ Stat 20(4):518-529

Stulz R (2015) Risk-taking and risk management by banks. J Appl Corp Financ 27(1):8-16

Sun J, Liu G (2014) Audit committees and oversight of bank risk taking. J Bank Financ 40:376-387

Swamy V (2018) Basel III capital regulations and bank profitability. Rev Financ Econ 36(2018):307-320

Switzer L, Wang J (2013) Default risk estimation, bank credit risk, and corporate governance. Financ Mark Inst Instrum 22(2):91-112

Tanda A (2015) The role of regulatory pressure in banks' capital and risk decisions. Int J Euro-Mediterr Stud 8(1):1-23

Tang J (2016) Duality and firm perfromance: the moderating roles of other executives and blockholding outside directors. Eur Manag J 35(2017):362-372

Tetlock P (2007) Giving content to investor sentiment: the role of media in the stock market. J Financ 62(3):1139-1168

Tonello, M. (2011). Separation of Chair and CEO roles. Harvard Law School Corporate Governance and Financial Regulation. Available at: https://corpgov.law.harvard.edu/2011/09/01/separation-ofchair-and-ceo-roles/ (Accessed 1 February 2015)

Tosun O, Senbet L (2019) Does internal board monitoring affect debt maturity? Rev Quant Financ Account. https://doi.org/10.1007/s11156-018-00787-z

Vallascas F, Mollah S, Keasey K (2017) Does the impact of board independence on large bank risks change after a global financial crisis? J Corp Financ 44:49-166

Walker D (2009) A review of corporate governance in UK banks. Available at: http://webarchive.nationalar chives.gov.uk/+/http:/www.hmtreasury.gov.uk/d/walker_review_261109.pdf. Accessed 3 Jan 2015

Wang C (2011) Board size and firm risk-taking. Rev Quant Financ Acc 2012(38):519-542. https://doi. org/10.1007/s11156-011-0241-4

Wang G, DeGhetto K, Ellen B, Lamont B (2019) Board antecedents of duality and moderating role of country level managerial discretion: a meta-analytic investigation. J Manag Stud 56(1):172-200

Yang T, Zhou S (2014) Duality and firm performance: evidence from an exogenous shock to the competitive environment. J Bank Financ 49(2014):534-552

Zagorchev A, Gao L (2015) Corporate governance and performance of financial institutions. J Econ Bus 82(2015):17-41 
Zhou X (2001) Understanding the determinants of managerial ownership and the link between ownership and performance: comment. J Financ Econ 62:559-571

Publisher's Note Springer Nature remains neutral with regard to jurisdictional claims in published maps and institutional affiliations. 